\title{
SIZE AND DEVELOPMENT OF THE SHADOW ECONOMY AND OF DO-IT-YOURSELF ACTIVITIES IN GERMANY
}

\author{
ANDREAS BÜHN \\ ALEXANDER KARMANN \\ FRIEDRICH SCHNEIDER
}

CESIFO WORKING PAPER NO. 2021

CATEGORY 1: PUBliC FinANCE

JUNE 2007

An electronic version of the paper may be downloaded

- from the SSRN website:

www.SSRN.com

- from the RePEc website:

Www.RePEc.org

- from the CESifo website:

www.CESifo-group.de 


\title{
SiZE AND DEVELOPMENT OF THE SHADOW ECONOMY AND OF DO-IT-YOURSELF ACTIVITIES IN GERMANY
}

\begin{abstract}
This paper presents the first MIMIC (multiple indicator multiple causes) model estimate of the size and development of the shadow economy and of do-it-yourself (DIY) activities in Germany from 1970 to 2005 . By 2005, they reached a level of about $17 \%$ and $4.94 \%$. While the shadow economy has regularly increased over the years, DIY activities - though quite sizeable - have remained more or less constant since the early 1990s. The driving forces for the shadow economy are regulation and tax burden whereas for DIY activities, the level of unemployment is the main factor.
\end{abstract}

JEL Code: O17, O5, D78, H2, H11, H26.

Keywords: shadow economy, do-it-yourself activities, tax burden, regulation, domestic currency in circulation, unemployment, MIMIC models.

\author{
Andreas Bühn \\ Department of Economics \\ University of Dresden \\ Helmholtzstr. 10 \\ 01069 Dresden \\ Germany \\ andreas.buehn@tu-dresden.de
}

\author{
Alexander Karmann \\ Department of Economics \\ University of Dresden \\ Helmholtzstr. 10 \\ 01069 Dresden \\ Germany \\ gkw@mailbox.tu-dresden.de
}

Friedrich Schneider

Johannes Kepler University Linz

Altenbergerstr. 69

4040 Linz-Auhof

Austria

friedrich.schneider@jku.at 


\section{Introduction}

Shadow economic and DIY activities are a fact of life around the world. Do-ityourself activities are generally seen as something positive and creative while the shadow economy is treated differently - that is, in a much more negative way. Most societies attempt to control the shadow economy through punishment or by relying on "official" economic growth or on education. Very often, shadow economic and DIY activities are seen as substitutes (e.g. if it is too risky to demand shadow economic activities, I only undertake DIY ones) or as complements (since I am capable of doing certain things, and if I do it myself it goes more quickly, I do not need to demand all services in the shadow economy.) Both types of activity are seen as a way to mitigate financial constraints (I can save money if the official economy is too expensive). The magnitudes at which shadow economic and DIY activities occur are not only important for academics, but also for politicians and the public. Gathering such statistics requires accurate information about who is engaged in the shadow economy and DIY activities and the frequencies with which these activities occur. It is difficult to obtain such information because individuals engaged in shadow economic activities do not readily volunteer details about these activities. Measuring DIY activities, however, is no less challenging as this is also a neglected area and has not been officially measured so far. ${ }^{4}$

Consequently, the estimation of the shadow economy and of DIY activities becomes a scientific passion to know the unknown. Although quite a large amount of literature on particular aspects of the shadow economy as well as a

\footnotetext{
4 First, pioneering measurements of do-it-yourself activities have been undertaken by Karmann (1990) where some elementary hypotheses on shadow economy and do-it-yourself activities causes were derived, and a simple empirical demand-sided analysis was undertaken.
} 
comprehensive survey exist, the subject remains controversial. ${ }^{5}$ Moreover, the authors are not aware of any studies which try to simultaneously estimate both the shadow economy and DIY activities. The major goal of this paper, therefore, is to provide such an estimation as well as to track the development of the shadow economy and DIY activities in Germany from 1970 to 2005. Further goals are to consider the impact of German reunification on shadow economic and DIY activities, to employ a proper estimate of domestic currency in circulation within Germany as an indicator variable for the shadow economy, and finally, to examine how sensitive these results are and how robust the (latent) estimation procedure - in this case the MIMIC model - is.

Chapter 2 provides a short review of hitherto existing estimates of the German shadow economy. It also defines the shadow economy and DIY activities and proposes theoretical considerations as to why people turn to shadow economic and DIY activities. Chapter 3 presents the empirical results, starting with the causal and indicator variables, followed by the econometric estimation result of the MIMIC models and, finally, the size and development of the shadow economy and of DIY activities in Germany. Chapter 4 summarizes and draws some policy conclusions. In the appendices, sources of the data used are provided, and some further robustness test results and estimations are presented.

\footnotetext{
${ }^{5}$ See Frey and Pommerehne (1984), Thomas (1992), Loyaza (1996), Pozo (1996), Lippert and Walker (1997), Schneider (1994a,b, 1997, 1998a,b, 2003, 2005), Johnson et.al. (1997, 1998a,b), Belev (2003), Gerxhani (2003), and Pedersen (2003). For surveys of evidence, see Schneider and Enste (2000, 2002), Schneider (2003) and Alm et.al. (2004).
} 


\section{Some Theoretical Considerations}

\subsection{Short Literature Review}

Existing estimates of the German shadow economy (measured in percentage of official GDP) are shown in Table 2.1. ${ }^{6}$ The oldest estimate uses the survey method of the Institute for Demoscopy in Allensbach, Germany and shows that the shadow economy was 3.6\% of official GDP in 1974. In a much later study, Feld and Larsen (2005) undertook an extensive research project using the survey method to estimate shadow economic activities in the years 2001 and 2004. ${ }^{7}$ Using the officially paid wage rate, they concluded that these activities reached $4.1 \%$ in 2001 and $3.1 \%$ in 2004. Using the (much lower) shadow economy wage rate, however, these estimates shrink to $1.3 \%$ and $1.0 \%$, respectively. If we look at the discrepancy method, for which we have estimates from 1970 to 1980, the German shadow economy is much larger: using the discrepancy between expenditure and income, we get approximately $11 \%$ for the 1970 s, and using the discrepancy between official and actual employment, roughly 30\%. The physical input methods where estimates for the 1980s are available deliver values of around $15 \%$ for the second half of that decade. The (monetary) transaction approach developed by Feige (1996) places the shadow economy at 30\% between 1980 and 1985. Yet another monetary approach, the currency demand approach - the first person to undertake an estimation for Germany was Kirchgässner $(1983,1984)$ - provides values of 3.1\% (1970) and 10.1\% (1980). Kirchgässner's values are quite similar to the ones obtained by Schneider and Enste (2000, 2002), who also used a currency demand approach to value the size of the shadow economy at $4.5 \%$ in 1970 and $14.7 \%$ in 2000. Finally, if we look

\footnotetext{
${ }^{6}$ A similar table can be found in Feld, Schmidt and Schneider (2007).

${ }^{7}$ In our paper there is no extensive discussion about the various methods to estimate the size and development of the shadow economy, also we do not discuss the strength and weaknesses of each method. Compare for this Schneider and Enste (2000), Schneider (2005), Feld and Larsen (2005), Pedersen (2003), and Giles (1999a,b,c).
} 
at latent (DY)MIMIC estimation procedures, the first ones being conducted by Frey and Weck-Hannemann in 1984, and later, Schneider and others followed for Germany, again, the estimations for the 1970s are quite similar. Furthermore, Schneider's estimates using a DYMIMIC approach (Schneider $(2005,2007))$ are close to those of the currency demand approach.

Thus, we can see that different estimation procedures produce different results. It is safe to say that the figures produced by the transaction and the discrepancy approaches are rather unrealistically large: the size of the shadow economy at almost one-third of official GDP in the mid-1980s is most likely an overestimate. The figures obtained using the currency demand and hidden variable (latent) approaches, on the other hand, are relatively close together and much lower than those produced by other methods (i.e. the discrepancy or transaction approaches). This similarity is not surprising given the fact that the estimates of the shadow economy using the latent (MIMIC) approach were measured by taking point estimates from the currency demand approach. Still, what is lacking is a consistent estimate of the shadow economy and of DIY activities. This is the goal of our paper. 
Table 2.1

The Size of the Shadow Economy in Germany According to Different Methods (in Percentage of Official GDP)

\begin{tabular}{|c|c|c|c|c|c|c|c|c|c|}
\hline \multirow[t]{2}{*}{ Method } & \multicolumn{8}{|c|}{ Shadow economy (in percentage of official GDP) in: } & \multirow[t]{2}{*}{ Source } \\
\hline & 1970 & 1975 & 1980 & 1985 & 1990 & 1995 & 2000 & 2005 & \\
\hline \multirow[t]{3}{*}{ Survey } & - & $3.6^{1)}$ & - & - & - & - & - & - & IfD Allensbach (1975) \\
\hline & - & - & - & - & - & - & $4.1^{2)}$ & $3.1^{2)}$ & \multirow[t]{2}{*}{ Feld and Larsen (2005) } \\
\hline & - & - & - & - & - & - & $1.3^{3)}$ & $1.0^{3)}$ & \\
\hline $\begin{array}{l}\text { Discrepancy between expenditure } \\
\text { and income }\end{array}$ & 11.0 & 10.2 & 13.4 & - & - & - & - & - & Lippert and Walker (1997) \\
\hline $\begin{array}{l}\text { Discrepancy between official and } \\
\text { actual employment }\end{array}$ & 23.0 & 38.5 & 34.0 & - & - & - & - & - & Langstedt (1983) \\
\hline Physical input method & - & - & - & 14.5 & 14.6 & - & - & - & \multirow[t]{2}{*}{ Feld and Larsen (2005) } \\
\hline Transactions approach & 17.2 & 22.3 & 29.3 & 31.4 & - & - & - & - & \\
\hline \multirow[t]{3}{*}{ Currency demand approach } & 3.1 & 6.0 & 10.3 & - & - & - & - & - & Kirchgässner (1982) \\
\hline & 12.1 & 11.8 & 12.6 & - & - & - & - & - & Langfeldt $(1983,1984)$ \\
\hline & 4.5 & 7.8 & 9.2 & 11.3 & 11.8 & 12.5 & 14.7 & - & Schneider and Enste (2000) \\
\hline \multirow[t]{3}{*}{ Latent ((DY)MIMIC) approach } & 5.8 & 6.1 & 8.2 & - & - & - & - & - & Frey and Weck (1984) \\
\hline & - & - & 9.4 & 10.1 & 11.4 & 15.1 & 16.3 & - & Pickardt and Sarda (2006) \\
\hline & 4.2 & 5.8 & 10.8 & 11.2 & 12.2 & 13.9 & 16.0 & 15.4 & Schneider (2005, 2007) \\
\hline Soft modelling & - & $8.3^{4)}$ & - & - & - & - & - & - & Weck-Hannemann (1983) \\
\hline
\end{tabular}

1) 1974.

2) 2001 and 2004; calculated using wages in the official economy.

3) 2001 and 2004; calculated using actual "black” hourly wages paid. 


\subsection{Defining the Shadow Economy and DIY Activities}

Most authors attempting to measure the shadow economy face the difficulty of how to define it. One commonly used working definition is all currently unregistered economic activities that contribute to the officially calculated (observed) Gross National Product. ${ }^{8}$ Smith (1994, p. 18) defines it as, "marketbased production of goods and services, whether legal or illegal that escapes detection in the official estimates of GDP”. One of the broadest definitions includes "those economic activities and the income derived from them that circumvent government regulation, taxation or observation". 9 As these definitions still leave a lot of questions open, Table 2.2 is helpful for developing a reasonable consensus on the definition of the shadow economy.

\footnotetext{
${ }^{8}$ This definition is used for example, by Feige (1989, 1994), Schneider (1994a, 2003) and Frey and Pommerehne (1984). For early, demand-sided estimates of the shadow economy and do-it-yourself activities for Germany see Karmann (1990).

9 This definition is taken from Del'Anno (2003), Del'Anno and Schneider (2004) and Feige (1989); see also Thomas (1999), Fleming, Roman and Farrell (2000).
} 
Table 2.2

A Taxonomy of Types of Economic Activities ${ }^{1)}$

\begin{tabular}{|l|l|l|l|l|}
\hline Type of activity & \multicolumn{2}{|c|}{ Monetary transactions } & \multicolumn{2}{|c|}{ Non-monetary transactions } \\
\hline Illegal activities & $\begin{array}{l}\text { Trade in stolen goods, drug } \\
\text { dealing and manufacturing, } \\
\text { prostitution, gambling, smuggling, } \\
\text { fraud, etc. }\end{array}$ & $\begin{array}{l}\text { Barter of drugs, stolen goods, } \\
\text { smuggling, etc., production or } \\
\text { growing of drugs for own use, } \\
\text { theft for own use. }\end{array}$ \\
\hline Legal activities & $\begin{array}{l}\text { Tax evasion } \\
\text { income from } \\
\text { self- } \\
\text { employment, } \\
\text { wages, salaries } \\
\text { and assets from } \\
\text { unreported work } \\
\text { related to } \\
\text { official/ lawful } \\
\text { goods and } \\
\text { services. }\end{array}$ & $\begin{array}{l}\text { Taxployee } \\
\text { discounts, } \\
\text { fringe benefits. }\end{array}$ & $\begin{array}{l}\text { Barter of } \\
\text { official/lawfulg } \\
\text { oods and } \\
\text { services. }\end{array}$ & $\begin{array}{l}\text { All do-it- } \\
\text { yourself work } \\
\text { and neighbourly } \\
\text { help. }\end{array}$ \\
\hline
\end{tabular}

${ }^{1)}$ Structure of table taken from Lippert and Walker (1997, p. 5) with additional remarks.

From Table 2.2, it becomes clear that a broad definition of the shadow economy includes unreported income from otherwise official trade in goods and services, e.g. through monetary or barter transactions - and thus includes all economic activities that would generally be taxable were they reported to governmental (tax) authorities. In this paper, the following, more narrow definition of the shadow economy is used: ${ }^{10}$ the shadow economy includes all market-based, lawful trade in goods and services that are deliberately concealed from public authorities for one of the following reasons:

(1) to avoid payment of income, value added or other taxes;

(2) to avoid payment of social security contributions;

\footnotetext{
${ }^{10}$ Compare also the excellent discussion on the definition of the shadow economy in Pedersen (2003, pp.13-19), who uses a similar one.
} 
(3) to avoid having to meet certain legal labour market standards, such as minimum wages, maximum working hours, safety standards, etc.; or,

(4) to avoid compliance with certain administrative procedures, such as filling in statistical questionnaires or other administrative forms.

Similarly, DIY activities include all market-based goods and services which are produced do-it-yourself in order to avoid gross wage payments, including taxes and social security contributions, in the official economy or to avoid any net wage payments in the shadow economy. It is important to note, however, that the main difference between DIY and shadow economic activities is that the former are entirely legal.

This paper shall not deal with typical, underground criminal activities, such as burglary, robbery, drug dealing, etc., which are all illegal. Rather, this paper investigates neglected shadow economic and lawful DIY activities in order to estimate their size. The term hidden economy is always used when considering the combined sector of shadow and do-it-yourself activities.

\subsection{Main Causes of Shadow Economic and DIY Activities}

\subsubsection{Tax and Social Security Contribution Burdens}

Studies point to tax and social security burdens as one of the main reasons for the existence of the shadow economy. ${ }^{11}$ Since taxes affect labour-leisure choices as well as stimulate labour supply in the shadow economy, the distortion of the overall tax burden is a major concern for economists. The greater the difference between the total cost of labour in the official economy and the after-tax

\footnotetext{
${ }^{11}$ See Thomas (1992); Lippert and Walker (1997); Schneider (1994a,b, 1997, 1998a,b, 2000, 2003); Johnson et.al. (1998a,b,); Tanzi (1999); Giles (1999a); Mummert and Schneider (2001); Giles and Tedds (2002), Giles et.al. (2002) and Dell'Anno (2003).
} 
earnings from work is, the more incentive people have to avoid this difference by working in the shadow economy. The studies of Schneider (1994b, 2000) and Johnson et.al. (1998a, 1998b) provide statistically significant empirical evidence of the influence of tax burdens on the shadow economy. The strong influence of indirect and direct taxation on the shadow economy is further demonstrated through the empirical results in Austria and the Scandinavian countries (Schneider (1986), (1994 a, b)). In contrast to shadow economic activities, the effect of tax burdens on DIY activities is more ambiguous as higher taxation may also drive up prices for do-it-yourself goods, thereby making do-it-yourself work more costly. This effect may countervail the distortion effect on official labour supply.

\subsubsection{Intensity of Regulation}

The intensity of regulation (often measured by the amount of laws and regulations, such as license requirements, or by the size of staff at regulatory agencies) is another important factor. An increase reduces the freedom (of choice) for individuals engaged in the official economy. ${ }^{12}$ Examples would be labour market regulations, trade barriers, and labour restrictions on foreigners. Johnson et.al. (1998b) find significant empirical evidence of the influence of (labour) market regulations on the shadow economy. The impact is also clearly described and theoretically derived in other studies, for example in the findings of the Deregulation Commission 1990/91 (Germany). Regulations lead to a substantial increase in labour costs in the official economy, but since most of these costs can be shifted onto employees they provide an incentive to work in the shadow economy - where they can be avoided.

\footnotetext{
${ }^{12}$ For a (social) psychological, theoretical foundation of this feature, see Brehm $(1966,1972)$, and for a (first) application to the shadow economy, see Pelzmann (1988).
} 


\subsubsection{Other Influential Factors}

\section{(1) Unemployment}

Obviously, the higher the unemployment is, the higher the incentive to be engaged in DIY activities. Unemployed people have less money for purchasing goods and services and therefore a higher incentive to engage in DIY activities. Additionally, DIY activities may enhance the unemployed's self-esteem, thereby further stimulating DIY activities.

\section{(2) Average gross hourly earnings}

It is also apparent that the higher the average gross hourly earnings in the "official” small trade sector are, the higher the costs are for people who demand such services. Given that people have the ability to do these activities themselves, we postulate that higher average gross hourly earnings lead to an increase in the volume of DIY activities, ceteris paribus.

\section{(3) Real disposable income}

Since real disposable income is positively correlated to demand for goods and services in general, we hypothesize that the higher the real disposable income is, the greater the demand not only in the official but also in the unofficial economy is and hence the larger the shadow economy is.

\subsubsection{Summarizing our Hypotheses}

After defining the shadow economy and DIY activities and providing some theoretical considerations on why people work in the shadow economy or are 
engaged in DIY activities, we would like to reiterate our hypotheses. Because it is not clear whether shadow economic and DIY activities can be treated as complements or substitutes - they may have both functions under different circumstances - we do not formulate any hypotheses about the interaction between these activities. Instead, we undertake the first (to our knowledge) proper attempt to simultaneously estimate the shadow economy and DIY activities according to the following hypotheses:

(1) An increase in tax and social security burdens increases shadow economic and DIY activities, ceteris paribus.

(2) The more the German economy is regulated, the greater the incentive is to work in the shadow economy, ceteris paribus.

(3) The higher the unemployment in Germany is, the more people engage in DIY activities, ceteris paribus.

(4) The higher the total wage cost in the official economy is, the more people undertake DIY activities, ceteris paribus.

\subsection{Indicator Variables of Shadow Economic and DIY Activities}

The MIMIC estimation procedure assumes that cause variables influence the shadow economy whereas indicator variables reflect shadow economic activities. In addition to the variables which contribute to the size and development of the shadow economy, we have four indicator variables that reflect shadow economic activities themselves.

The first indicator variable is the domestic currency in circulation, i.e. cash outside the banking system in the form of coins and banknotes that can be physically held in the hand. This amount of currency is typically used for dayto-day expenses but also for shadow economic activities. 
Here, we formulate the following four hypotheses:

(5) The larger the shadow economy is, the more currency (measured in real currency) there is in circulation, ceteris paribus.

If the official real GDP growth rate is low, the incentive to engage in the shadow economy rises. In other words, the lower the level of official activity is, the fewer possibilities people have to earn more money or to obtain employment in the official economy. For this reason, we formulate the following hypothesis:

(6) The lower the growth rate of real GDP is, the larger the shadow economy is, ceteris paribus.

On the other hand, the reverse causation could also hold true, i.e. the higher the economic growth, the larger the shadow economy. One explanation is that if the official economy grows, the shadow economy may grow as well since favourable conditions for economic growth apply for both the official as well as the unofficial economy and especially since additional goods purchased (e.g. cars) in the official economy lead to a demand in maintenance and other services in the shadow economy.

The average hours worked per week in the official economy is also an important indicator for shadow economic activities. The more people work in the official economy, the less time they have to be engaged in the shadow economy. We therefore formulate the following hypothesis:

(7) The more people work - measured by the average hours worked per week in the official economy, the smaller the shadow economy is, ceteris paribus. 
Do-it-yourself activities are best reflected in the estimated real turnover in DIY stores. Thus, we formulate our last hypothesis:

(8) The greater the amount of DIY activities is, the higher the estimated real turnover in DIY stores is, ceteris paribus.

\section{Empirical Results: the Hidden Economy in Germany}

\subsection{Data Sources}

Our data cover the period 1970 to 2005 on an annual basis. All data except that on tax and social security contributions, on domestic currency in circulation, and on turnover in DIY stores are taken from the Federal Statistical Office of Germany. The latter were made available by A.C. Nielsen Company GmbH and cover 1978 to 2005. The estimated growth rates from 1970 to 1977 are used to predict the level of turnover in DIY stores for this period. For the approximation of tax and social security contribution burdens, we use public revenue data provided by the Organisation for Economic Co-operation and Development (OECD). The main components are income tax, value added and sales taxes, social security contributions, and payroll taxes.

Data on domestic currency in circulation are taken from the Deutsche Bundesbank. From the 1950s to 2001, DM-denominated currency in circulation outside the banking system greatly increased and cannot be examined on the basis of domestic transactions in the official and unofficial economies alone. One possible explanation is the rise in foreign demand for the Deutsche Mark during that time. ${ }^{13}$ The bulk of foreign demand in the 1990s stemmed from

\footnotetext{
${ }^{13}$ Seitz (1995).
} 
Eastern and Southeast Europe after the breakdown of the Council for Mutual Economic Assistance (COMECON) system. Unstable political circumstances in the early 1990s, the war in Kosovo, and the Bulgarian Financial Crisis of 1996/1997 increased foreign demand for the Deutsche Mark further. Given that we are interested in shadow economic and DIY activities in Germany only, it is essential to focus on domestic currency demand as an indicator variable for the shadow economy. For this reason, we exclude foreign demand for the Deutsche Mark from the total amount of currency in circulation (provided by the Deutsche Bundesbank) and instead use the methodology proposed by Seitz (1995) to assess domestic demand for currency in circulation. We then apply this methodology both to take German reunification into account and to adjust for the distortion in domestic currency in circulation during the second half of 2001 as a result of the public's preparation for the introduction of the Euro (in 2002). At that time, people substituted cash with demand deposits in order to avoid personally exchanging their Deutsche Mark for Euros. ${ }^{14}$ This triggered an enormous decrease in domestic currency in circulation which cannot be attributed to changes in shadow economic or DIY activities. The details of our estimation procedures are provided in subsections 5.2. and 5.3 of the Appendix, which also provides a complete list of data sources in Table 5.1.

Before proceeding, we shall test our data for stationarity. The results are discussed in the next subsection.

\subsection{Unit Root Tests}

Applying MIMIC models ${ }^{15}$ with nonstationary time series may result in misleading estimates. To overcome this problem and to avoid spurious

\footnotetext{
${ }^{14}$ Deutsche Bundesbank (2002).

${ }^{15}$ One of the first studies using this approach over time was that of Aigner, Schneider and Ghosh (1985), who estimated the shadow economy of the United States.
} 
regressions, we conduct the Phillips and Perron (PP) unit root test ${ }^{16}$ to check for the presence of a unit root in a particular times series. For the series in levels, an intercept and a time trend are included. The Schmidt-Phillips unit root test as proposed by Schmidt and Phillips (1992) is employed to cross check the presence of a unit root. Table 5.2 in the Appendix displays the results. In all cases, except for the variable average gross hourly earnings (Wages) - where both tests show inconsistent results - we cannot reject the null hypothesis of a unit root at the $5 \%$ significance level. As a result, we treat the variables as I(1) and differenced them once to achieve stationarity. In this case, we employ the Kwiatkowski, Phillips, Schmidt, and Shin (KPSS) test ${ }^{17}$ to cross check the results from the PP test. For most variables, we cannot reject the null hypothesis of stationarity at the 5\% significance level. Only for the variables Income and Reg are the values of the test statistic slightly greater than the $5 \%$ critical value. As the time series for the turnover in DIY stores (Tdiy) remains nonstationary even after taking first differences, the approach suggested by Schwert (1987) is employed to detrend the time series of the variable Tdiy successfully. Because of the limited sample size, the lag order is set to two. The findings from our unit root tests are displayed in Table 3.1.

\footnotetext{
${ }^{16}$ Phillips and Perron (1988).

${ }^{17}$ Kwiatkowski et al. (1992). 
Table 3.1

Results of Unit Root Tests for the Variables Used

\begin{tabular}{lcccc}
\hline \hline & \multicolumn{2}{c}{ PP test } & \multicolumn{2}{c}{ KPSS test } \\
\hline Variable & Test statistic & Lag length & Test statistic & Lag length \\
\hline Curr & -3.5121 & 6 & 0.3840 & 2 \\
Grgdp & -4.0100 & 1 & 0.1869 & 1 \\
Hours & -3.0728 & 1 & 0.1358 & 4 \\
Income & -4.5613 & 2 & 0.5149 & 3 \\
Inf & -5.2178 & 6 & 0.0562 & 3 \\
Reg & -4.7745 & 0 & 0.6024 & 2 \\
Tdiy & & & & \\
(first difference) & -1.4123 & 0 & 0.4460 & 2 \\
Tdiy & & & & \\
(detrended) & -5.3301 & 2 & 0.0687 & 1 \\
Tbur & -3.6901 & 0 & 0.4460 & 2 \\
Unemp & -3.5503 & 11 & 0.3979 & 2 \\
Wages & -4.1005 & 2 & 0.4521 & 4 \\
\hline \hline
\end{tabular}

The order of the autoregressive correction for both tests was chosen using the Bartlett kernel estimator and the Newey-West (1994) data-based automatic bandwidth parameter method. All regressions include an intercept but no time trend. The critical values for the PP test - taken from MacKinnon (1996) are: -3.64 (1\% level), -2.95 (5\% level), and -2.61 (10\% level). The LM statistics critical values of the KPSS test - taken from Kwiatkowski et al. (1992) - are: 0.7390 (1\% level), 0.4630 (5\% level), and 0.3470 (10\% level).

Table 3.2 presents a detailed description of the variables ultimately used in the MIMIC models as well as all data transformations carried out to achieve stationarity for the respective variables. 
Table 3.2

Variables Used in the MIMIC Model

\begin{tabular}{|c|c|}
\hline Variable used & Description of the variable used \\
\hline \multicolumn{2}{|c|}{ Indicator variables } \\
\hline Curr & $\begin{array}{l}\text { First difference of the natural logarithm of the level of real domestic } \\
\text { currency in circulation as estimated in section 5.2. }\end{array}$ \\
\hline Grgdp & Growth rate of real GDP. \\
\hline Hours & $\begin{array}{l}\text { First difference of the natural logarithm of the average hours worked per } \\
\text { week. }\end{array}$ \\
\hline Tdiy & $\begin{array}{l}\text { Detrended natural logarithm of the real turnover in do-it-yourself stores } \\
\text { as explained in section 5.3. }\end{array}$ \\
\hline \multicolumn{2}{|l|}{ Causes variables } \\
\hline Dummy & $\begin{array}{l}\text { One for the years } 1991 \text { and } 1992 \text { to cover impulse effects in the } \\
\text { differenced variables as a result of German reunification, null else. }\end{array}$ \\
\hline Income & $\begin{array}{l}\text { First difference of the natural logarithm of the per capita real disposable } \\
\text { income in Germany. }\end{array}$ \\
\hline Inf & $\begin{array}{l}\text { First difference of the natural logarithm of the ratio of current year's CPI } \\
\text { to previous year's CPI. }\end{array}$ \\
\hline Reg & $\begin{array}{l}\text { First difference of the ratio of the number of people employed in public } \\
\text { service (excluding people employed by railways and the postal service, } \\
\text { which were previously state-run) to total population. }\end{array}$ \\
\hline Tbur & First difference of the per capita public revenues for Germany. \\
\hline Unemp & $\begin{array}{l}\text { First difference of the natural logarithm of the number of unemployed } \\
\text { people. }\end{array}$ \\
\hline Wages & $\begin{array}{l}\text { First difference of the natural logarithm of the average gross hourly } \\
\text { earnings of male workers in the small trade sector. }\end{array}$ \\
\hline
\end{tabular}

As a result of data transformation, the model is estimated in first differences and thus provides estimations of latent variables in first differences only. Consequently, we must integrate the resulting time series in differences to obtain the index series for the shadow economy (S), DIY and the hidden economy spectrum $(\mathrm{H})$.

\subsection{MIMIC Models}

Our estimation of the shadow economy and of DIY activities is based on two alternative model specifications. The first (S-DIY) model considers shadow economic and DIY activities as two distinct latent variables that will be estimated simultaneously in a MIMIC model. Following our earlier hypotheses, 
we use the variables measuring both tax and social security contribution burdens as well as the intensity of regulation as the main elements to describe shadow economic activities. Do-it-yourself activities, however, are best explained through unemployment, tax and social security contribution burdens, and average gross hourly earnings. Despite the ambiguous theoretical effect of higher inflation on the shadow economy and on DIY activities, we consider inflation as a causal variable for the latent variables in our MIMIC models. Since inflationary pressure lowers nominal tax burdens, we expect increasing inflation to have a negative impact on the amount of both shadow economic and DIY activities. Furthermore, we use a dummy variable (Dummy) to control for structural changes of the German economy and impulse effects on the data as a result of German reunification in 1990. The conceptual diagram of the S-DIY model is shown in Figure 3.1.

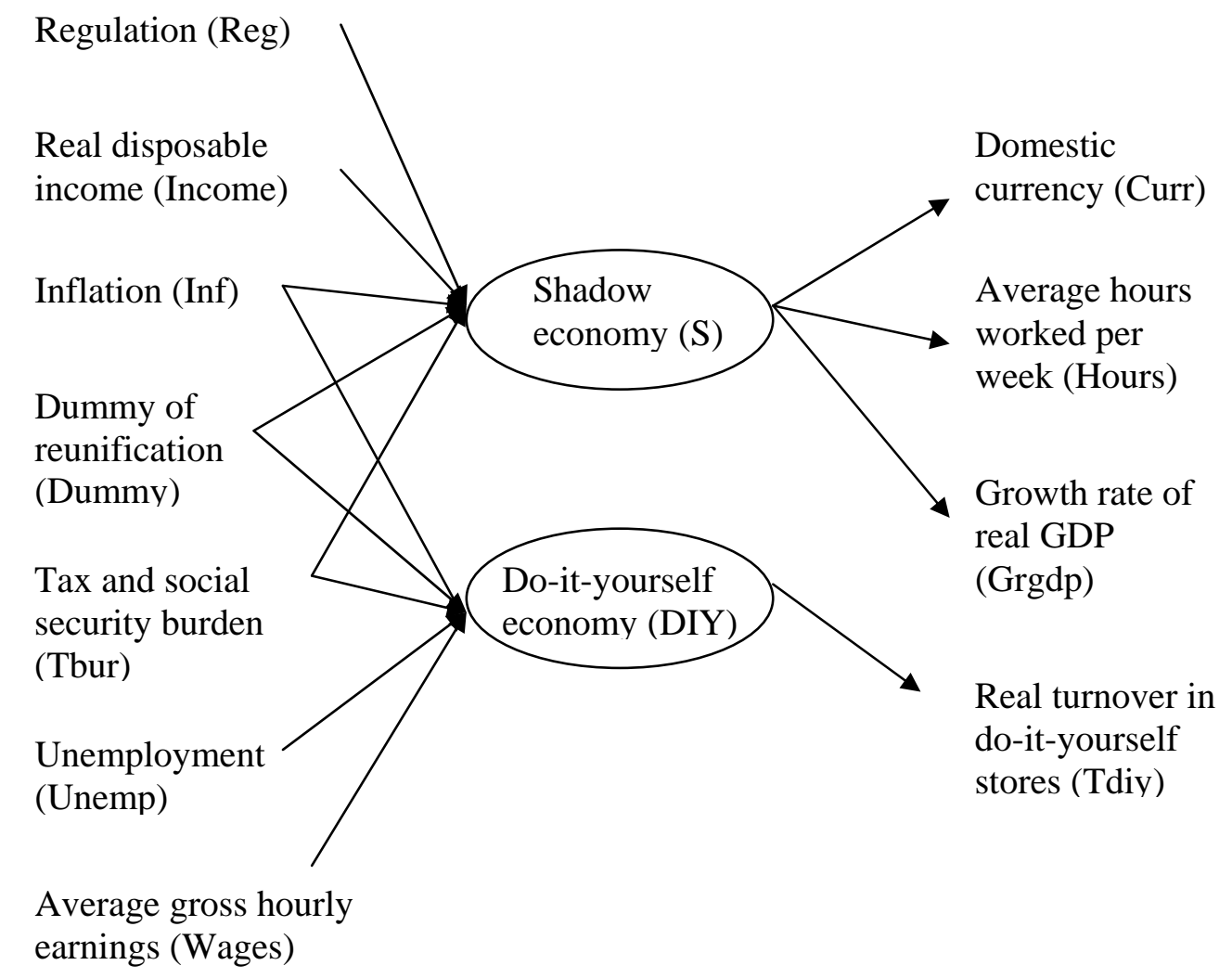

Fig. 3.1 Conceptual Diagram of the S-DIY MIMIC Model 
To confirm the S-DIY model, we estimate a second (H-DIY) model specification. In this H-DIY model, the hidden economy spectrum, $\mathrm{H}$, is estimated using the same causal variables used for the estimation of the shadow economy in the S-DIY model. As illustrated in Figure 3.2, DIY activities are then determined by the causal link between latent variables and are measured as a percentage of the overall hidden economy. The size of the shadow economy is derived by subtracting DIY activities from the hidden economy.

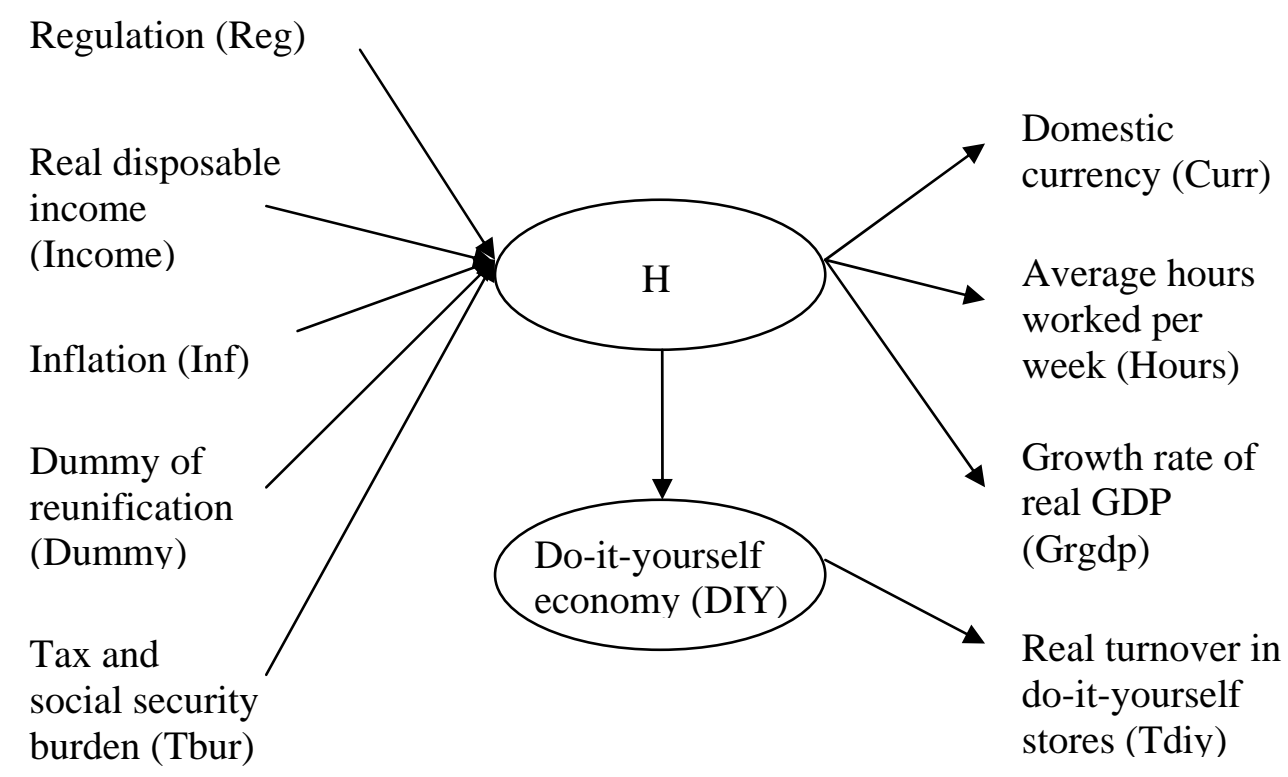

Fig. 3.2 Conceptual Diagram of the H-DIY MIMIC Model

Since $\mathrm{S}$ is a decisive part of $\mathrm{H}$, all indicator variables used for $\mathrm{S}$ must also be considered for $\mathrm{H}$. Hence, the same set of indicator variables is employed in both model specifications.

As indicators of the shadow economy, we use the growth rate of real GDP (Grgdp), the estimated domestic currency in circulation (Curr), and the average hours worked per week (Hours). For the latent DIY activities, we use turnover in 
DIY stores in Germany (Tdiy) as a particularly suitable indicator. The results of both MIMIC model estimations, applying the maximum likelihood estimator for the S-DIY model as well as for the H-DIY model are shown in Table 3.3. For each model specification, the first column shows the parameter estimates for both causal as well as indicator variables for $\mathrm{S}$ and $\mathrm{H}$. The parameter estimates relating to DIY activities are displayed in the second column. The last two rows in Table 3.3 refer to the causal link between H and DIY in the H-DIY model.

The following summarizes our findings from the estimation of the presented MIMIC models and addresses our proposed hypotheses.

(1)The intensity of regulation is always highly statistically significant and is positively related to $\mathrm{S}$ and $\mathrm{H}$, having the expected sign.

(2) Tax and social security contribution burdens are statistically significant different from zero for $\mathrm{S}$ as well as for $\mathrm{H}$ and are, as expected, positively related to both latent variables. We cannot confirm that the tax burden is a driving factor for the public to engage in DIY activities.

(3) In both model specifications, the variable Income, which measures per capita real disposable income, is highly statistically significant and positively related to $\mathrm{S}$ and $\mathrm{H}$. One possible explanation is that the higher the disposable income of households, the higher the demand for goods and services. Demand rises not only in the official economy but also, in part, in the shadow economy, leading to a higher observed level of shadow economic activity. This implies that both sectors are complementary to each other.

(4) The variable Inf is statistically different from zero for DIY activities only; that is, the inflation rate influences DIY activities and has a negative sign. As was previously mentioned, it is not clear from the literature whether inflation appears with a positive or negative sign. With a negative sign, a possible interpretation is that the higher the inflation rate - which makes raw materials 
for DIY activities more expensive - the fewer activities individuals perform, leading to a lower level of the latent variable DIY. The negative, though insignificant, influence of inflation on shadow activities, given all other causal factors, may be seen as contributing to a reduction in real tax burdens, thereby reducing incentives to avoid taxation.

(5) The dummy variable which measures the impact of German reunification in 1990 is positively related to both shadow economic and to DIY activities, as well as to the hidden economy spectrum. The variable is always highly statistically significant, has the expected sign, and reflects the catching up process after the reunification of both economies.

(6) The unemployment level is an important factor in DIY activities. The variable, Unemp, is positively related to the respective latent variable and has the expected sign.

(7) In our MIMIC models, hourly earnings in the small trade sector, measured by the variable Wages, do not influence do-it-yourself activities since the relationship between the variable Wages and DIY is not statistically different from zero. Nevertheless, the parameter estimate has the expected sign, showing that higher wages lower the demand for small trade services and hence raise the incentives for the public to engage in DIY activities.

With regard to the indicator variables, we fix one indicator for each latent variable. For the shadow economy, we choose the variable Curr. For the latent variable indicating DIY activities, we opt for the variable Tdiy. For the two remaining indicators, we obtain the following results:

(8) The estimated coefficient on the Grgdp indicator variable is statistically different from zero and hence suggests a positive relationship between the shadow economy and the growth rate of real GDP. 
(9) For the second indicator variable, Hours, we cannot confirm that the size of the shadow economy affects the average hours worked per week. The estimated coefficient is always statistically insignificant at any reasonable significance level.

Table 3.3

MIMIC Model Results and Parameter Estimates

\begin{tabular}{lcccc}
\hline & \multicolumn{2}{c}{ S-DIY model } & \multicolumn{2}{c}{ H-DIY model } \\
& $\mathrm{S}$ & DIY & $\mathrm{H}$ & DIY \\
\hline \multicolumn{2}{l}{ Indicator variables } & & & \\
Curr & 1.00 & & 1.00 & \\
Grgdp & $0.25^{* * *}$ & & $0.22^{* * *}$ & \\
& $(3.32)$ & & $(3.22)$ & \\
Hours & -0.02 & & -0.01 & \\
& $(-1.32)$ & & $(-1.10)$ & 2.00 \\
Tdiy & & 2.00 & & \\
\hline
\end{tabular}

Causes variables

\begin{tabular}{lccc} 
Reg & $11.98^{* *}$ & & $11.24^{* *}$ \\
& $(2.54)$ & & $(2.51)$ \\
Income & $1.38^{* * *}$ & & $1.43^{* * *}$ \\
& $(3.34)$ & & $(3.54)$ \\
Inf & -0.32 & $-0.53^{* *}$ & -0.93 \\
& $(-0.50)$ & $(-2.44)$ & $(-1.44)$ \\
Dummy & $0.10^{* *}$ & $0.05^{* * *}$ & $0.13^{* * *}$ \\
& $(2.50)$ & $(4.18)$ & $(3.29)$ \\
Tbur & $0.11^{* *}$ & -0.01 & $0.09^{* *}$ \\
& $(2.37)$ & $(-0.37)$ & $(2.07)$ \\
Unemp & & $0.03^{* *}$ & \\
& & $(2.14)$ & \\
Wages & & 0.15 & \\
& & $(0.85)$ & \\
\hline
\end{tabular}

Latent Variable

$\mathrm{H} \quad 0.13^{* *}$

(2.05)

T-statistics appear in parenthesis. $*=$ significance at $10 \%$ level, $* *=$ significance at $5 \%$ level, $* * *=$ significance at $1 \%$ level.

In order to estimate not only the relative size but also the levels of our latent variables, it is necessary to fix a scale for each latent variable used. A convenient albeit somewhat arbitrary way is to set the coefficient of one 
indicator variable of the measurement model to non-zero, thereby simplifying examination of the relative magnitude of the other indicator variables. ${ }^{18}$ We set the coefficient of the variable Curr to one since the size of the shadow economy is measured in monetary units. Because we are dealing with two latent variables simultaneously, it is also necessary to fix the other unobserved variable, DIY. Our decision to set the coefficient of the indicator variable Tdiy to two is based on the following theoretical consideration: ${ }^{19}$ capital productivity measures the ratio of output to capital input, indicating the value added in a specific business sector. Since we employ the capital input of DIY activities, i.e. turnover in DIY stores, as an indicator for the unobserved variable DIY, i.e. the output, the use of capital productivity as a fixed parameter seems to be appropriate. Assuming that the value added in the construction business is nearly equal to that of DIY activities, we choose an approximate value of capital productivity for the construction business in 1991 (the approximate mid-point of our observation period). According to the Federal Statistical Office of Germany, capital productivity in the construction business was 1.89 in 1991.

As Table 3.3 also shows, all variables except Hours and Tbur are significant at the $5 \%$ significance level for both $\mathrm{S}$ as well as for $\mathrm{H}$. With regard to the latent variable DIY, only the variable Tbur is not statistically significant. We also estimate both model specifications but exclude the insignificant variables. The parameter estimates, nevertheless, remain stable, as can be seen from the last column of Tables 5.3 and 5.4 in the Appendix. In addition, we employ robustness checks by varying the observation period. Again, parameter estimates remain rather stable (see Table 5.3 and Table 5.4). The test statistics representing the overall fit of the S-DIY and H-DIY models and the parsimonious model specifications excluding the insignificant variables are displayed in Table 3.4.

\footnotetext{
${ }^{18}$ Giles and Tedds, 2002, p. 109.

${ }^{19}$ For similar arguments see also Karmann (1990). 
Table 3.4

Summary Statistics of the Estimated MIMIC Model

\begin{tabular}{lcccc}
\hline \hline & \multicolumn{2}{c}{ Full model } & \multicolumn{2}{c}{ Parsimonious model } \\
\hline & S-DIY & H-DIY & S-DIY & H-DIY \\
\hline $\begin{array}{l}\text { Degrees of freedom } \\
\begin{array}{l}\text { Chi-square } \\
\text { (p-Value) }\end{array}\end{array}$ & 50 & 33 & 34 & 19 \\
$\begin{array}{l}\text { Root mean squared } \\
\text { error of }\end{array}$ & $(0.9486)$ & $(0.6077)$ & $(0.8718)$ & $(0.9231)$ \\
$\begin{array}{l}\text { approximation } \\
\text { (RMSEA) }\end{array}$ & 0.0000 & 0.0000 & 0.0000 & 0.0000 \\
$\begin{array}{l}\text { P-value for test of } \\
\text { close fit }\end{array}$ & & & & \\
$\begin{array}{l}\text { (RMSEA < 0.05) } \\
\text { Root mean square } \\
\text { residual (RMR) }\end{array}$ & 0.9800 & 0.7300 & 0.9800 & 0.9500 \\
$\begin{array}{l}\text { Standardized RMR } \\
\text { Goodness of fit index } \\
\text { (GFI) }\end{array}$ & 0.0003 & 0.0005 & 0.0003 & 0.0006 \\
$\begin{array}{l}\text { Adjusted goodness of } \\
\text { fit index (AGFI) }\end{array}$ & 0.087 & 0.12 & 0.087 & 0.095 \\
$\begin{array}{l}\text { Parsimony goodness } \\
\text { of fit index (PGFI) }\end{array}$ & 0.80 & 0.78 & 0.84 & 0.92 \\
\hline \hline
\end{tabular}

Overall, the global goodness of fit statistics of the various model specifications show satisfactory statistical properties. Nevertheless, for the S-DIY model, the statistics of the full model indicate a slightly closer fit compared to the parsimonious one whereas for the H-DIY model, the reverseis true. To assure comparability between the estimates of both the S-DIY and the H-DIY model, we always use the full model specifications to predict the size of shadow economic and DIY activities in Germany from 1970 to 2005. We refrain from displaying the global goodness of fit statistics for robustness checks with variations in the observation period since they do not differ much from those of the full models. 


\subsection{Size of the Shadow Economy and of DIY Activities}

One difficulty of MIMIC model estimations is that the obtained ordinal series needs to be converted into a cardinal series. In the literature, this is usually done by calibration using an absolute level of the estimate at a particular time within an observation period. Since we employ the first differences of the variables in the MIMIC models, the latent variable is estimated under the same transformation. In order to obtain the actual values of the shadow economy and DIY activities as a percentage of official GDP, an a priori known value is required. This can be done by using the average of estimates from a number of other studies (Schneider and Enste, 2000). One can also identify such a benchmark, however, by estimating a cardinal series through some other approach, for example, the cash demand approach (Giles and Tedds, 2002). In this paper, we refer to the estimate obtained by Karmann (1990) for the size of DIY activities in Germany since it is (to our knowledge) the only estimate that exists. To be consistent with the results obtained in this study, we also take the estimate for the size of the shadow economy from Karmann (1990). Thus, we apply the shadow economy estimate of $8.5 \%$ and the DIY estimate of $4.4 \%$ to scale up our ordinal series. Both benchmark point estimates refer to 1983. The complete cardinal series we identify are shown in Figures 3.3-3.5. Figure 3.3 plots the size and development of the shadow economy according to the S-DIY model. It shows a remarkable increase in the shadow economy over the past 25 years, reaching $17.40 \%$ of official GDP in 2005. German reunification in 1990 triggered a steep rise in the shadow economy during the reconstruction period that followed. After East Germany caught up to West Germany's behavioural patterns, growth in the shadow economy slowed down considerably to the current level of around $17 \%$. 


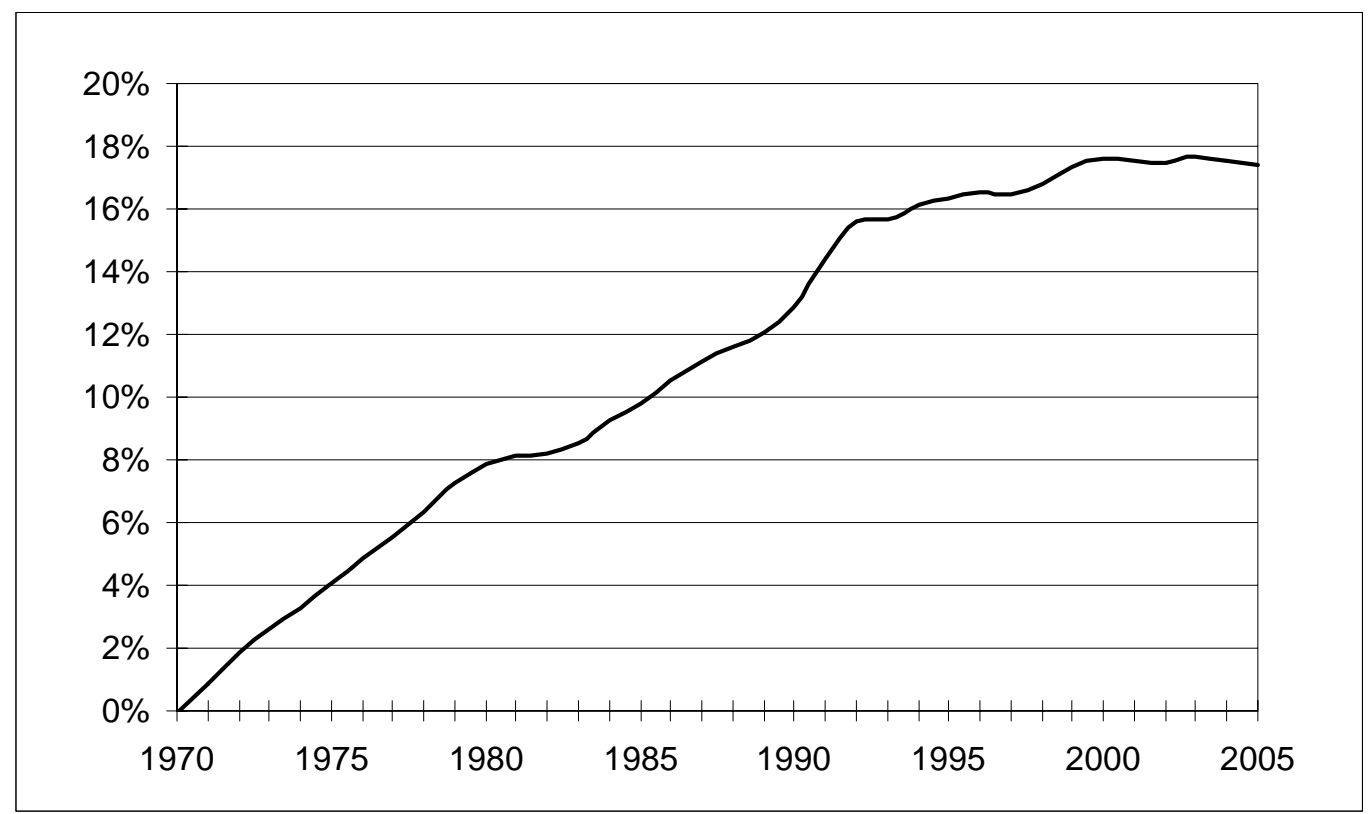

Fig. 3.3 Shadow Economy in Germany in Percentage of GDP (1990:2005)

Figure 3.4 illustrates the estimated size and development of DIY activities under the S-DIY model specification. Do-it-yourself activities as a percentage of official GDP increased from 4.05\% in 1970 to $4.94 \%$ in 1995 and remained more or less stable through 2005. Like shadow economic activities, DIY activities also experienced a big push following German reunification - even though the dynamics were not as pronounced. On the whole, between 1970 and 2005, DIY activities grew more slowly than did the shadow economy. 


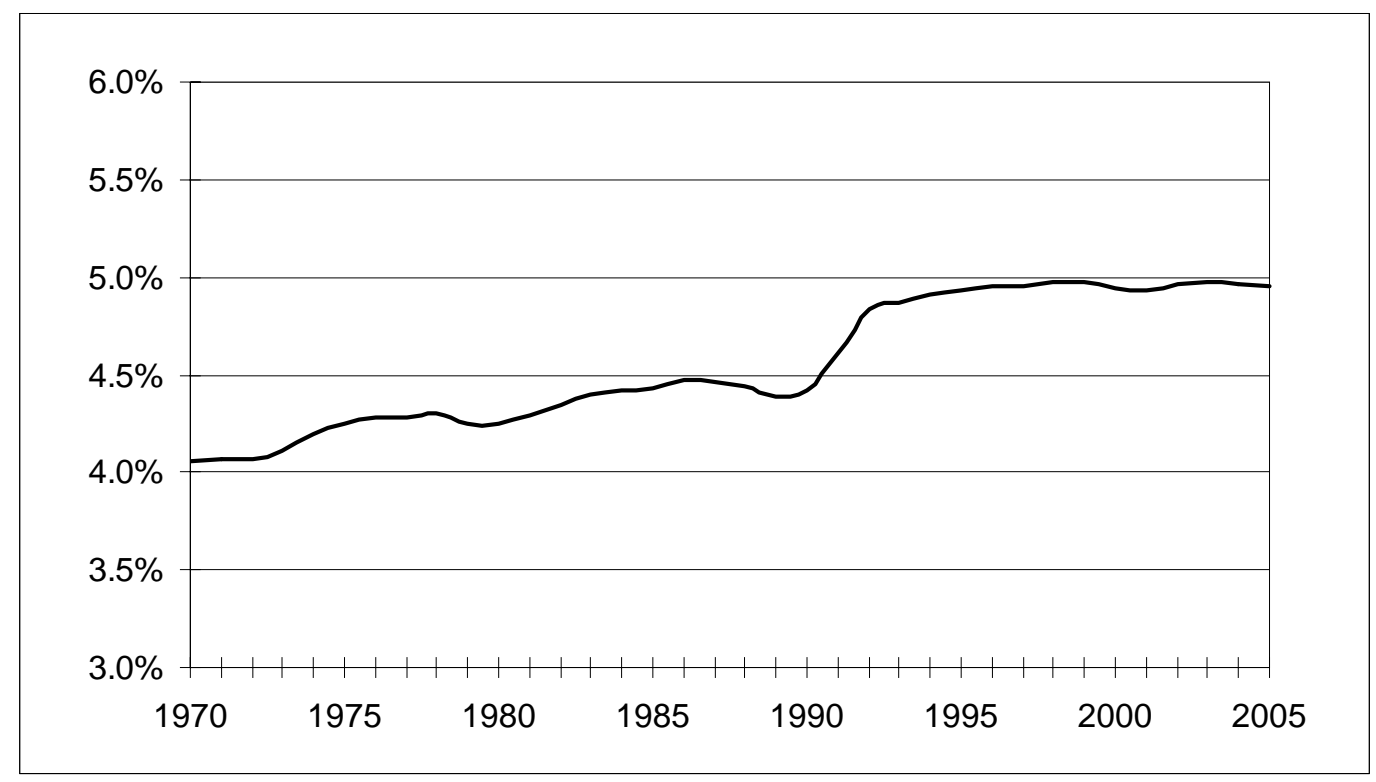

Fig. 3.4 DIY Activities in Germany in Percentage of GDP (1970:2005)

When calculating the size and development of shadow economic and DIY activities in Germany according to the H-DIY model, we obtain similar results. As Figure 3.5 shows, DIY activities ranged from 3.87\% (1970) to 4.99\% (2005) whereas the shadow economy increased from $1.63 \%$ (1970) to $16.11 \%$ (2005). Accordingly, the benchmark value for the H-index is simply derived by adding the a priori known values for the shadow economy and for the DIY activities taken from Karmann (1990). As a result, our benchmark for the hidden economy in 1983 is $12.9 \%$ of official GDP. All estimates of the different index series according to the S-DIY and the H-DIY model are shown in Table 5.5 in the Appendix. 


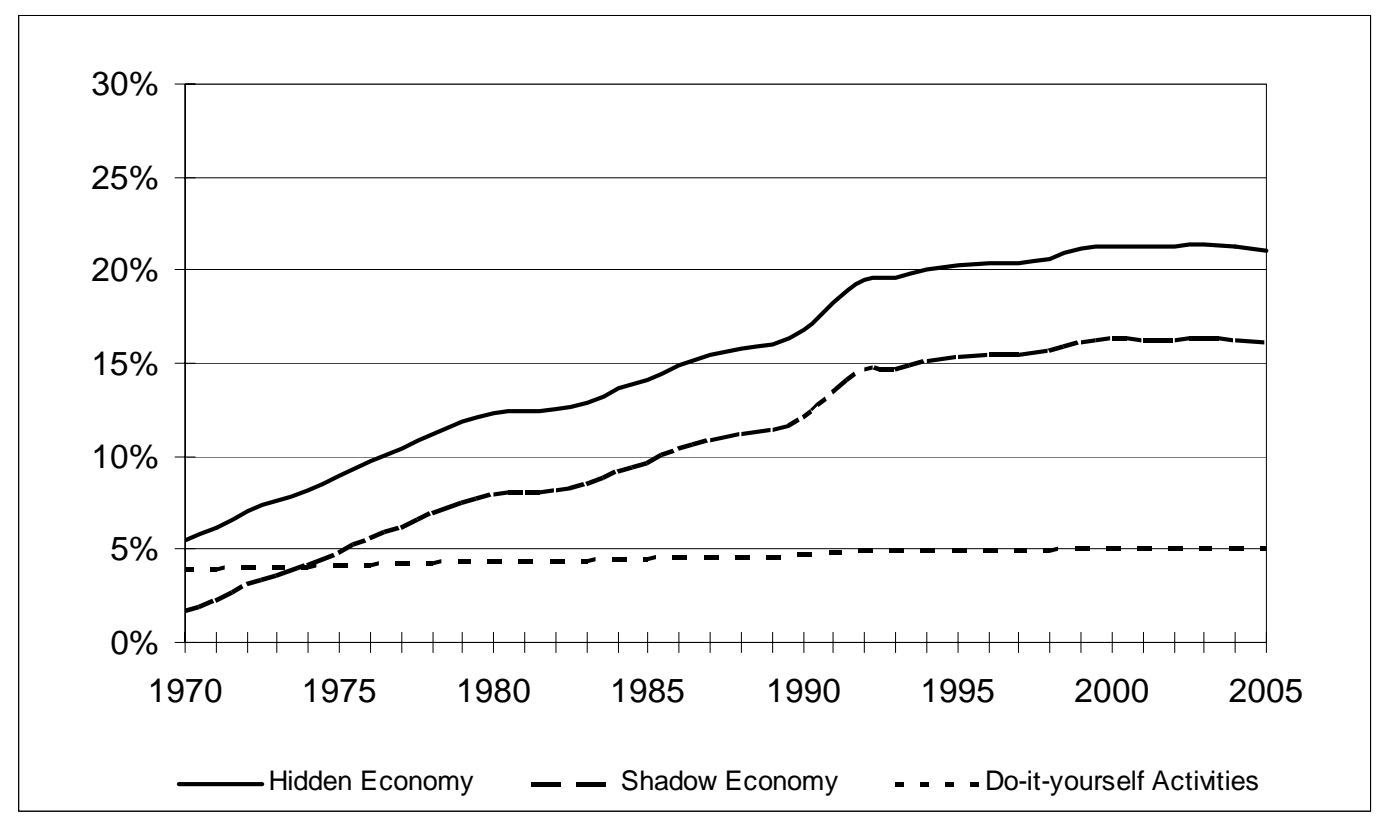

Fig. 3.5 Time Path of the Different Indices According to the H-DIY Model in Percentage of GDP (1970:2005) 


\section{Summary and Conclusions}

In this paper, we have used a latent estimation approach, here, a MIMIC model, to provide the first consistent estimate of the size and development of the shadow economy and of DIY activities in Germany. In addition, we found a highly statistically significant influence of regulation as well as tax and social security contribution burdens on the shadow economy. For DIY activities, we observed a highly statistically significant positive influence of unemployment. In general, the estimated MIMIC model shows satisfactory statistical properties. According to our calculations the German shadow economy increased from 2\% in 1970 to $17 \%$ in 2005 . These results are very similar to those obtained by Schneider (2005) using the currency demand approach (compare table 2.1). Doit-yourself activities amounted to 4\% of official GDP in 1970, increased to $4.94 \%$ in 1995, and remained relatively constant till 2005. Taking both sectors together, we see that the hidden economy in Germany reached a remarkable size of more than 20\% of official GDP in 2005.

What type of policy conclusions can we draw from these results?

(1) The simultaneous and consistent estimation of conjoint shadow economic and DIY activities yields values of 16\% of official GDP for the former and $5 \%$ of official GDP for the latter for the past 4-5 years.

(2) If one wants to reduce the shadow economy and/or DIY activities, our results indicate that fewer regulations and lower tax and social security contribution burdens might be the two most efficient means of shifting more activity into the official economy. Reducing both the intensity of regulation and the amount of contributions to the social security system in Germany might also result in a lower level of unemployment. This would reduce the public's incentive to engage in DIY activities. 
(3) Though our results should be regarded as first steps in measuring the size of the hidden economy, we have demonstrated that both shadow economic and DIY activities are important and should be taken into account when seeking to stimulate the official economy through policy measures. 


\section{Appendix}

\subsection{Tables}

Table 5.1

Data Sources

\begin{tabular}{ll}
\hline \hline Variable & Data source \\
\hline CPI & Federal Statistical Office of Germany \\
Curr & Deutsche Bundesbank, own calculations \\
GDP & Federal Statistical Office of Germany \\
Grgdp & Own calculations \\
Hours & Federal Statistical Office of Germany \\
Income & Deutsche Bundesbank \\
Inf & Own calculations \\
Reg & Federal Statistical Office of Germany, own calculations \\
Total population & Federal Statistical Office of Germany (Thomsen Financial \\
& Datastream) \\
Tdiy & A.C. Nielsen Company GmbH, own calculations \\
Tbur & Organisation for Economic Co-operation and Development \\
& (OECD) \\
Unemp & Federal Statistical Office of Germany \\
Wages & Federal Statistical Office of Germany, own calculations \\
\hline \hline
\end{tabular}


Table 5.2

Unit Root Tests for the Time Series in Levels

\begin{tabular}{|c|c|c|c|c|}
\hline \multirow{2}{*}{$\overline{\text { Variable }}$} & \multicolumn{2}{|c|}{ PP test } & \multicolumn{2}{|c|}{ Schmidt-Phillips test } \\
\hline & Test statistic & Lag length & Test statistics & Lag length $l_{q}$ \\
\hline \multirow[t]{2}{*}{$\overline{\text { Curr }}$} & -1.6614 & 2 & -1.6453 & 3 \\
\hline & & & -1.6827 & 9 \\
\hline \multirow[t]{2}{*}{ Hours } & -1.3969 & 4 & -1.3356 & 3 \\
\hline & & & -1.5648 & 9 \\
\hline \multirow[t]{2}{*}{ Income } & -1.7008 & 0 & -1.7062 & 3 \\
\hline & & & -1.6475 & 9 \\
\hline \multirow[t]{2}{*}{ Inf } & -2.8782 & 1 & -2.4181 & 3 \\
\hline & & & -1.4623 & 9 \\
\hline \multirow[t]{2}{*}{ Reg } & -0.6600 & 6 & -1.2617 & 3 \\
\hline & & & -1.4921 & 9 \\
\hline \multirow[t]{2}{*}{ Tdiy } & -1.0553 & 4 & -1.1893 & 3 \\
\hline & & & -1.4762 & 9 \\
\hline \multirow[t]{2}{*}{ Tbur } & -1.0229 & 3 & -1.7221 & 3 \\
\hline & & & -1.7460 & 9 \\
\hline \multirow{2}{*}{ Unemp } & -2.5858 & 2 & -2.7828 & 3 \\
\hline & & & -1.5601 & 9 \\
\hline \multirow[t]{2}{*}{ Wages } & -4.8518 & 1 & -0.4709 & 3 \\
\hline & & & -0.5398 & 9 \\
\hline \multicolumn{5}{|c|}{$\begin{array}{l}\text { The order of the autoregressive correction for the PP test was chosen } \\
\text { using the Bartlett kernel estimator and the Newey-West (1994) data- } \\
\text { based automatic bandwidth parameter method. All regressions for the PP } \\
\text { test include an intercept and a time trend. The critical values for the PP } \\
\text { test }- \text { taken from MacKinnon (1996) - are: }-4.24 \text { ( } 1 \% \text { level), }-3.54 \text { (5\% } \\
\text { level), and }-3.20 \text { ( } 10 \% \text { level). The suggestion for the choice of the lag- } \\
\text { length in the Schmidt-Phillips test is to use } l_{q}=q(T / 100)^{1 / 4} \text {, where } \\
q=4 \text { or } q=12 \text {, which results in a lag-length of } 3 \text { and } 9 \text {, respectively. } \\
\text { The critical values for this test }- \text { tabulated in Schmidt and Phillips } \\
\text { (1992) - are: }-3.55 \text { (1\% level), }-3.02 \text { (5\% level), and }-2.75 \text { (10\% level). }\end{array}$} \\
\hline
\end{tabular}


Table 5.3

Robustness Checks S-DIY MIMIC Model

\begin{tabular}{|c|c|c|c|c|c|c|c|c|c|c|c|c|c|c|}
\hline & \multicolumn{2}{|c|}{ 1971-2005 } & \multicolumn{2}{|c|}{ 1972-2005 } & \multicolumn{2}{|c|}{ 1973-2005 } & \multicolumn{2}{|c|}{ 1970-2004 } & \multicolumn{2}{|c|}{ 1970-2003 } & \multicolumn{2}{|c|}{ 1970-2002 } & \multicolumn{2}{|c|}{$\begin{array}{c}\text { Ex insignificant } \\
\text { variables } \\
(1970-2005)\end{array}$} \\
\hline & $\mathbf{S}$ & DIY & $\mathbf{S}$ & DIY & $\mathbf{S}$ & DIY & $\mathrm{S}$ & DIY & $\mathbf{S}$ & DIY & $\mathrm{S}$ & DIY & $\mathrm{S}$ & DIY \\
\hline \multicolumn{15}{|c|}{ Indicator variables } \\
\hline Curr & 1 & & 1 & & 1 & & 1 & & 1 & & 1 & & 1 & \\
\hline Grgdp & $0.27 * * *$ & & $0.27 * * *$ & & $0.26 * * *$ & & $0.27 * * *$ & & $0.30 * * *$ & & $\begin{array}{c}0.25 * * * \\
(3.07)\end{array}$ & & $0.28 * * *$ & \\
\hline Hours & $\begin{array}{c}-0.02 \\
(-1.31)\end{array}$ & & $\begin{array}{c}-0.02 \\
(-1.16)\end{array}$ & & $\begin{array}{c}-0.02 \\
(-1.12)\end{array}$ & & $\begin{array}{c}-0.02 \\
(-1.17)\end{array}$ & & $\begin{array}{l}-0.02 \\
(1.04)\end{array}$ & & $\begin{array}{c}-0.01 \\
(-0.77)\end{array}$ & & & \\
\hline Tdiy & & 2 & & 2 & & 2 & & 2 & & 2 & & 2 & & 2 \\
\hline \multicolumn{15}{|c|}{ Causes variables } \\
\hline Reg & $\begin{array}{c}12.12^{* *} \\
(2.63)\end{array}$ & & $\begin{array}{c}12.17^{* *} \\
(2.59)\end{array}$ & & $\begin{array}{c}12.48 * * \\
(2.55)\end{array}$ & & $\begin{array}{c}11.83^{* *} \\
(2.55)\end{array}$ & & $\begin{array}{c}12.08 * * \\
(2.59)\end{array}$ & & $\begin{array}{c}13.08 * * \\
(2.63)\end{array}$ & & $\begin{array}{c}11.94^{* *} \\
(2.64)\end{array}$ & \\
\hline Income & $\begin{array}{c}1.34 * * * \\
(3.22)\end{array}$ & & $\begin{array}{c}1.34 * * * \\
(3.11)\end{array}$ & & $\begin{array}{c}1.41^{* * *} \\
(3.02)\end{array}$ & & $\begin{array}{c}1.34 * * * \\
(3.16)\end{array}$ & & $\begin{array}{c}1.25 * * * \\
(2.97)\end{array}$ & & $\begin{array}{c}1.45^{* * *} \\
(3.23)\end{array}$ & & $\begin{array}{c}1.28 * * * \\
(3.12)\end{array}$ & \\
\hline Inf & $\begin{array}{c}-0.25 \\
(-0.39)\end{array}$ & $\begin{array}{c}-0.62 * * \\
(-2.33)\end{array}$ & $\begin{array}{c}-0.24 \\
(-0.35)\end{array}$ & $\begin{array}{c}-0.59 * * \\
(-2.21)\end{array}$ & $\begin{array}{c}-0.35 \\
(-0.49)\end{array}$ & $\begin{array}{c}-0.58 * * \\
(-2.09)\end{array}$ & $\begin{array}{c}-0.27 \\
(-0.42)\end{array}$ & $\begin{array}{c}-0.57 * * \\
(-2.15)\end{array}$ & $\begin{array}{c}-0.11 \\
(-0.18)\end{array}$ & $\begin{array}{c}-0.55^{* *} \\
(-2.03)\end{array}$ & $\begin{array}{c}-0.49 \\
(-0.72)\end{array}$ & $\begin{array}{c}-0.54 * * \\
(-2.08)\end{array}$ & & $\begin{array}{c}-0.53 * * \\
(-2.28)\end{array}$ \\
\hline Dummy & $\begin{array}{c}0.09 * * \\
(2.38)\end{array}$ & $\begin{array}{c}0.05^{* * *} \\
(4.01)\end{array}$ & $\begin{array}{l}0.09 * * \\
(2.33)\end{array}$ & $\begin{array}{c}0.05 * * * \\
(3.86)\end{array}$ & $\begin{array}{c}0.09 * * \\
(2.34)\end{array}$ & $\begin{array}{c}0.04 * * * \\
(3.63)\end{array}$ & $\begin{array}{c}0.09 * * \\
(2.41)\end{array}$ & $\begin{array}{c}0.05 * * * \\
(3.92)\end{array}$ & $\begin{array}{c}0.09 * * \\
(2.29)\end{array}$ & $\begin{array}{c}0.05 * * * \\
(3.77)\end{array}$ & $\begin{array}{c}0.10 * * \\
(2.45)\end{array}$ & $\begin{array}{c}0.05^{* * *} \\
(4.08)\end{array}$ & $\begin{array}{c}0.09 * * \\
(2.37)\end{array}$ & $\begin{array}{c}0.04^{* * *} \\
(4.25)\end{array}$ \\
\hline Tbur & $\begin{array}{l}0.11^{* *} \\
(2.34)\end{array}$ & $\begin{array}{c}-0.01 \\
(-0.35)\end{array}$ & $\begin{array}{l}0.11^{* *} \\
(2.28)\end{array}$ & $\begin{array}{c}-0.01 \\
(-0.35)\end{array}$ & $\begin{array}{c}0.11 * * \\
(2.22)\end{array}$ & $\begin{array}{c}-0.01 \\
(-0.35)\end{array}$ & $\begin{array}{c}0.11^{* *} \\
(2.29)\end{array}$ & $\begin{array}{c}-0.00 \\
(-0.27)\end{array}$ & $\begin{array}{c}0.12^{* *} \\
(2.43)\end{array}$ & $\begin{array}{c}-0.01 \\
(-0.44)\end{array}$ & $\begin{array}{l}0.12 * * \\
(2.18)\end{array}$ & $\begin{array}{c}0.00 \\
(0.08)\end{array}$ & $\begin{array}{l}0.09 * * \\
(2.12)\end{array}$ & \\
\hline Unemp & & $\begin{array}{c}0.03^{* *} \\
(2.11)\end{array}$ & & $\begin{array}{c}0.03 * * \\
(2.04)\end{array}$ & & $\begin{array}{c}0.03^{*} \\
(1.86)\end{array}$ & & $\begin{array}{c}0.03 * * \\
(2.19)\end{array}$ & & $\begin{array}{c}0.03 * * \\
(2.15)\end{array}$ & & $\begin{array}{c}0.03 * * \\
(2.44)\end{array}$ & & $\begin{array}{c}0.04^{* * *} \\
(2.75)\end{array}$ \\
\hline Wages & & $\begin{array}{c}0.15 \\
(0.78)\end{array}$ & & $\begin{array}{c}0.16 \\
(0.78)\end{array}$ & & $\begin{array}{c}0.17 \\
(0.68)\end{array}$ & & $\begin{array}{c}0.11 \\
(0.58)\end{array}$ & & $\begin{array}{c}0.11 \\
(0.56)\end{array}$ & & $\begin{array}{c}0.09 \\
(0.46)\end{array}$ & & \\
\hline
\end{tabular}

T-statistics appear in parenthesis. $*=$ significance at $10 \%$ level, $* *=$ significance at $5 \%$ level, $* * *=$ significance at $1 \%$ level. 
Table 5.4

Robustness Checks H-DIY MIMIC Model

\begin{tabular}{|c|c|c|c|c|c|c|c|c|c|c|c|c|c|c|}
\hline & \multicolumn{2}{|c|}{ 1971-2005 } & \multicolumn{2}{|c|}{ 1972-2005 } & \multicolumn{2}{|c|}{ 1973-2005 } & \multicolumn{2}{|c|}{$1970-2004$} & \multicolumn{2}{|c|}{ 1970-2003 } & \multicolumn{2}{|c|}{ 1970-2002 } & \multicolumn{2}{|c|}{$\begin{array}{c}\text { Ex insignificant } \\
\text { variables } \\
(1970-2005)\end{array}$} \\
\hline & $\mathbf{H}$ & $\overline{D I Y}$ & $\mathbf{H}$ & DIY & $\mathbf{H}$ & DIY & $\mathbf{H}$ & DIY & $\mathbf{H}$ & DIY & $\mathbf{H}$ & DIY & $\mathbf{H}$ & DIY \\
\hline \multicolumn{15}{|c|}{ Indicator variables } \\
\hline Curr & 1 & & 1 & & 1 & & 1 & & 1 & & 1 & & 1 & \\
\hline Grgdp & $\begin{array}{c}0.23 * * * \\
(3.17)\end{array}$ & & $\begin{array}{c}0.21 * * * \\
(3.00)\end{array}$ & & $\begin{array}{c}0.20 * * * \\
(2.84)\end{array}$ & & $\begin{array}{c}0.23 * * * \\
(3.11)\end{array}$ & & $\begin{array}{c}0.25 * * * \\
(3.15)\end{array}$ & & $\begin{array}{c}0.22 * * * \\
(2.95)\end{array}$ & & $\begin{array}{l}0.29 * * \\
(2.43)\end{array}$ & \\
\hline Hours & $\begin{array}{c}-0.01 \\
(-1.10)\end{array}$ & & $\begin{array}{c}-0.01 \\
(-0.95)\end{array}$ & & $\begin{array}{c}-0.01 \\
(-0.91)\end{array}$ & & $\begin{array}{c}-0.01 \\
(-0.96)\end{array}$ & & $\begin{array}{c}-0.01 \\
(-0.83)\end{array}$ & & $\begin{array}{c}-0.01 \\
(-0.59)\end{array}$ & & & \\
\hline Tdiy & & 2 & & 2 & & 2 & & 2 & & 2 & & 2 & & 2 \\
\hline \multicolumn{15}{|c|}{ Causes variables } \\
\hline Reg & $\begin{array}{c}11.59 * * \\
(2.55)\end{array}$ & & $\begin{array}{c}11.46^{* *} \\
(2.45)\end{array}$ & & $\begin{array}{c}11.61^{* *} \\
(2.40)\end{array}$ & & $\begin{array}{c}11.17^{* *} \\
(2.44)\end{array}$ & & $\begin{array}{c}11.90^{* *} \\
(2.54)\end{array}$ & & $\begin{array}{c}11.71^{* *} \\
(2.43)\end{array}$ & & $\begin{array}{c}10.59 * * \\
(2.43)\end{array}$ & \\
\hline Income & $\begin{array}{c}1.40 * * * \\
(3.42)\end{array}$ & & $\begin{array}{c}1.43^{* * *} \\
(3.36)\end{array}$ & & $\begin{array}{c}1.48^{* * *} \\
(3.23)\end{array}$ & & $\begin{array}{c}1.39 * * * \\
(3.33)\end{array}$ & & $\begin{array}{c}1.38 * * * \\
(3.23)\end{array}$ & & $\begin{array}{c}1.43^{* * *} \\
(3.29)\end{array}$ & & $\begin{array}{c}1.18 * * * \\
(2.96)\end{array}$ & \\
\hline Inf & $\begin{array}{c}-0.86 \\
(-1.31)\end{array}$ & & $\begin{array}{c}-1.18 \\
(-1.63)\end{array}$ & & $\begin{array}{c}-1.70 * * \\
(-2.52)\end{array}$ & & $\begin{array}{c}-0.85 \\
(-1.29)\end{array}$ & & $\begin{array}{c}-0.68 \\
(-1.03)\end{array}$ & & $\begin{array}{c}-1.00 \\
(-1.44)\end{array}$ & & & \\
\hline Dummy & $\begin{array}{c}0.12^{* * *} \\
(3.13)\end{array}$ & & $\begin{array}{c}0.13^{* * *} \\
(3.22)\end{array}$ & & $\begin{array}{c}0.13^{* * *} \\
(3.20)\end{array}$ & & $\begin{array}{c}0.13^{* * *} \\
(3.15)\end{array}$ & & $\begin{array}{c}0.12 * * * \\
(2.96)\end{array}$ & & $\begin{array}{c}0.14^{* * *} \\
(3.21)\end{array}$ & & $\begin{array}{c}0.11^{* * *} \\
(2.77)\end{array}$ & \\
\hline Tbur & $\begin{array}{l}0.09 * * \\
(2.06)\end{array}$ & & $\begin{array}{l}0.09 * \\
(1.90)\end{array}$ & & $\begin{array}{l}0.09^{*} \\
(1.83)\end{array}$ & & $\begin{array}{l}0.09 * \\
(2.02) \\
\end{array}$ & & $\begin{array}{c}0.11 * * \\
(2.18) \\
\end{array}$ & & $\begin{array}{l}0.10^{*} \\
(1.96)\end{array}$ & & $\begin{array}{l}0.09 * \\
(2.01) \\
\end{array}$ & \\
\hline \multicolumn{15}{|c|}{ Latent variable } \\
\hline $\mathrm{H}$ & & $\begin{array}{l}0.13^{*} \\
(1.96)\end{array}$ & & $\begin{array}{l}0.13^{*} \\
(2.00)\end{array}$ & & $\begin{array}{l}0.13^{*} \\
(1.98)\end{array}$ & & $\begin{array}{l}0.13^{*} \\
(1.88)\end{array}$ & & $\begin{array}{c}0.11 \\
(1.58)\end{array}$ & & $\begin{array}{l}0.14^{*} \\
(2.00)\end{array}$ & & $\begin{array}{l}0.14 * \\
(1.82)\end{array}$ \\
\hline
\end{tabular}

T-statistics appear in parenthesis. $*=$ significance at $10 \%$ level, $* *=$ significance at $5 \%$ level, $* * *=$ significance at $1 \%$ level 
Table 5.5

Size of the Hidden Economy, the Shadow Economy and of DIY Activities (in Percentage of GDP) (1970:2005)

\begin{tabular}{|c|c|c|c|c|c|c|}
\hline & \multicolumn{2}{|c|}{ Tidden economy } & \multicolumn{2}{|c|}{ Shadow economy } & \multicolumn{2}{|c|}{ Do-it-yourself activities } \\
\hline Year & $\begin{array}{c}\text { H-DIY } \\
\text { model }\end{array}$ & $\begin{array}{l}\text { S-DIY } \\
\text { model }\end{array}$ & $\begin{array}{c}\text { H-DIY } \\
\text { model }\end{array}$ & $\begin{array}{l}\text { S-DIY } \\
\text { model }\end{array}$ & $\begin{array}{l}\text { H-DIY } \\
\text { model }\end{array}$ & $\begin{array}{l}\text { S-DIY } \\
\text { model }\end{array}$ \\
\hline 1970 & 4.02 & 5.50 & -0.04 & 1.63 & 3.87 & 4.05 \\
\hline 1971 & 4.92 & 6.16 & 0.86 & 2.24 & 3.92 & 4.07 \\
\hline 1972 & 5.95 & 7.08 & 1.88 & 3.10 & 3.98 & 4.07 \\
\hline 1973 & 6.71 & 7.57 & 2.60 & 3.55 & 4.02 & 4.11 \\
\hline 1974 & 7.48 & 8.17 & 3.28 & 4.11 & 4.06 & 4.20 \\
\hline 1975 & 8.34 & 8.97 & 4.09 & 4.85 & 4.12 & 4.25 \\
\hline 1976 & 9.16 & 9.76 & 4.88 & 5.59 & 4.17 & 4.28 \\
\hline 1977 & 9.84 & 10.37 & 5.56 & 6.15 & 4.22 & 4.28 \\
\hline 1978 & 10.65 & 11.17 & 6.35 & 6.90 & 4.28 & 4.30 \\
\hline 1979 & 11.52 & 11.88 & 7.27 & 7.55 & 4.33 & 4.25 \\
\hline 1980 & 12.11 & 12.28 & 7.85 & 7.93 & 4.36 & 4.25 \\
\hline 1981 & 12.43 & 12.45 & 8.14 & 8.09 & 4.37 & 4.29 \\
\hline 1982 & 12.58 & 12.54 & 8.23 & 8.17 & 4.37 & 4.35 \\
\hline 1983 & 12.90 & 12.90 & 8.50 & 8.50 & 4.40 & 4.40 \\
\hline 1984 & 13.66 & 13.60 & 9.24 & 9.15 & 4.45 & 4.42 \\
\hline 1985 & 14.23 & 14.10 & 9.80 & 9.61 & 4.49 & 4.43 \\
\hline 1986 & 15.01 & 14.92 & 10.54 & 10.38 & 4.55 & 4.47 \\
\hline 1987 & 15.61 & 15.44 & 11.14 & 10.86 & 4.58 & 4.47 \\
\hline 1988 & 16.03 & 15.77 & 11.59 & 11.16 & 4.61 & 4.44 \\
\hline 1989 & 16.47 & 16.03 & 12.08 & 11.41 & 4.62 & 4.39 \\
\hline 1990 & 17.31 & 16.78 & 12.90 & 12.10 & 4.68 & 4.42 \\
\hline 1991 & 19.03 & 18.24 & 14.42 & 13.45 & 4.78 & 4.61 \\
\hline 1992 & 20.44 & 19.50 & 15.60 & 14.63 & 4.87 & 4.84 \\
\hline 1993 & 20.56 & 19.56 & 15.68 & 14.68 & 4.88 & 4.87 \\
\hline 1994 & 21.05 & 20.05 & 16.15 & 15.13 & 4.91 & 4.91 \\
\hline 1995 & 21.26 & 20.25 & 16.32 & 15.32 & 4.93 & 4.94 \\
\hline 1996 & 21.46 & 20.40 & 16.51 & 15.46 & 4.94 & 4.96 \\
\hline 1997 & 21.44 & 20.33 & 16.48 & 15.40 & 4.93 & 4.96 \\
\hline 1998 & 21.76 & 20.65 & 16.79 & 15.69 & 4.96 & 4.97 \\
\hline 1999 & 22.29 & 21.12 & 17.31 & 16.13 & 4.99 & 4.97 \\
\hline 2000 & 22.56 & 21.30 & 17.61 & 16.29 & 5.00 & 4.94 \\
\hline 2001 & 22.48 & 21.23 & 17.54 & 16.23 & 5.00 & 4.94 \\
\hline 2002 & 22.46 & 21.23 & 17.50 & 16.23 & 5.00 & 4.96 \\
\hline 2003 & 22.63 & 21.39 & 17.66 & 16.38 & 5.01 & 4.97 \\
\hline 2004 & 22.48 & 21.23 & 17.51 & 16.23 & 5.00 & 4.96 \\
\hline 2005 & 22.35 & 21.10 & 17.40 & 16.11 & 4.99 & 4.96 \\
\hline
\end{tabular}




\subsection{Domestic Demand for Currency in Circulation in Germany}

The Goldfeld (1973) equation provides the analytical background for our approach. In equilibrium, real money demand is assumed to depend on real income and the level of short term interest rates. In countries with weak national currencies, however, two or more sound currencies are often used simultaneously as means of payment and as store of values. Like Seitz (1995), we take this fact into account and include the EUR/USD exchange rate to reflect both the relative strength of the Euro over the US-Dollar as well as the observation that both currencies are close substitutes in such countries. Dummy variables for the first and second quarter of 1991 are used to control for the impact of German reunification.

To predict the level of domestic currency in circulation, we apply a vector error correction model using the methodology developed in Johansen $(1991,1995)$ to detect cointegrating relations. Our data are on a quarterly basis from Q1 1970 to Q4 2005. The variable GDP, measuring real income, is expressed in logarithm. The data for currency in circulation and for the short term interest rate are taken from the Deutsche Bundesbank. Data for the German quarterly GDP and for the EUR/USD exchange rate are from Thomson Financial Datastream. All variables are found to be I(1). Applying the Johansen cointegration test for the long run part of the vector error correction model, we find one cointegration equation at the $5 \%$ significance level for the four variables under consideration. In order to achieve stationarity for the short run, we then difference all variables once. The results of the unit root tests as well as of the Johansen cointegration test are presented in Table 5.6. 
Table 5.6

Currency in Circulation

\begin{tabular}{|c|c|c|}
\hline \multirow[b]{2}{*}{ Variable } & \multicolumn{2}{|c|}{ PP unit root test } \\
\hline & Variable in levels & First difference \\
\hline Currency in circulation & $\begin{array}{l}-1.9506 \\
(0.6227)\end{array}$ & $\begin{array}{l}-11.8498 \\
(0.0000)\end{array}$ \\
\hline GDP & $\begin{array}{c}-1.4219 \\
(-0.8506)\end{array}$ & $\begin{array}{l}-11.9054 \\
(0.0000)\end{array}$ \\
\hline Short term interest rate & $\begin{array}{c}-3.0510 \\
(-0.1223)\end{array}$ & $\begin{array}{l}-9.2914 \\
(0.0000)\end{array}$ \\
\hline EUR/USD exchange rate & $\begin{array}{l}-1.3888 * * \\
(-0.8603)\end{array}$ & $\begin{array}{l}-9.7402 \\
(0.0000)\end{array}$ \\
\hline \multicolumn{3}{|l|}{ Cointegration test } \\
\hline Trace test & $\begin{array}{l}54.3611 \\
(0.0108)\end{array}$ & \\
\hline Maximum eigenvalue & $\begin{array}{l}30.0971 \\
(0.0233) \\
\end{array}$ & \\
\hline \multicolumn{3}{|c|}{$\begin{array}{l}\text { The order of the autoregressive correction for the PP unit root test was } \\
\text { chosen using the Bartlett kernel estimator and the Newey-West (1994) } \\
\text { data-based automatic bandwidth parameter method. All regressions } \\
\text { for the PP test in levels include an intercept and a time trend. The } \\
\text { critical values - taken from MacKinnon (1996) - are: }-4.02 \text { (1\% } \\
\text { level), -3.44 (5\% level), and -3.15 (10\% level). For the first difference } \\
\text { of the variables, the test includes an intercept only. Here, the critical } \\
\text { values (also from MacKinnon (1996)) are: -3.48 (1\% level), -2.88 (5\% } \\
\text { level), and -2.58 (10\% level). The } 5 \% \text { critical value for the trace and } \\
\text { maximum eigenvalue tests are } 47.86 \text { and } 27.58 \text {, respectively, and are } \\
\text { taken from MacKinnon et al. (1999). }\end{array}$} \\
\hline
\end{tabular}

The vector error correction model allows us to determine the level of domestic currency in circulation in accordance with the economic conditions in Germany from 1970 to 2005. Hence, we adjust the total amount of currency in circulation provided by the Deutsche Bundesbank by the fraction circulating abroad. Figure 5.6 shows the outcome. 


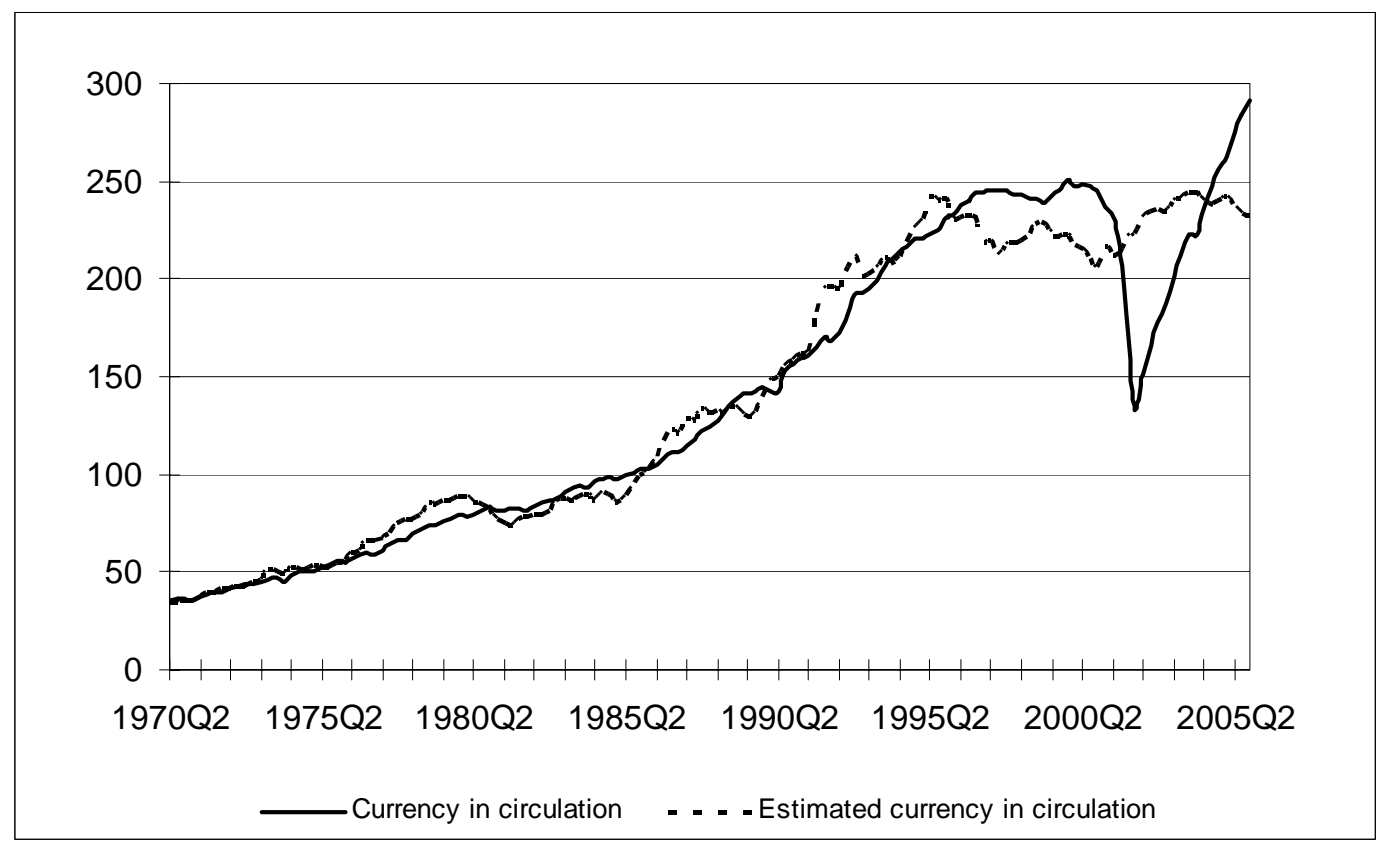

Fig. 5.6 Currency in Circulation in Billions of Euros (1970:2005) 


\subsection{Extrapolation of Turnover in German DIY stores}

Because the A.C. Nielsen Company GmbH conducted the first annual survey on turnover in DIY stores in Germany in 1978, completing the time series for the entire period 1970-2005 requires estimation of the turnover for the missing years. To do this, we first calculate the annual growth rates (Grtdiy) as the first difference of the natural logarithm of the initial time series. We then simply regress the obtained growth rates on a constant term and on time. Table 5.7 shows the results of this estimation.

Table 5.7

Regression of Grtdiy on a constant and on time

\begin{tabular}{|c|c|}
\hline Variable & Grtdiy \\
\hline \multicolumn{2}{|l|}{$\overline{\text { Parameter estimates }}$} \\
\hline Constant & $\begin{array}{c}0.2119 * * * \\
(0.0000)\end{array}$ \\
\hline Time & $\begin{array}{c}-0.0082^{* *} \\
(0.0000)\end{array}$ \\
\hline \multicolumn{2}{|l|}{ Test statistics } \\
\hline Standard error of regression & 0.03955 \\
\hline Adjusted $\mathrm{R}^{2}$ & 0.7131 \\
\hline DW-statistic & 2.57 \\
\hline \multicolumn{2}{|l|}{ Unit root tests } \\
\hline PP test & -6.3697 \\
\hline KPSS test & 0.0827 \\
\hline \multicolumn{2}{|c|}{$\begin{array}{l}\text { The order of the autoregressive correction for both unit root } \\
\text { tests was chosen using the Bartlett kernel estimator and the } \\
\text { Newey-West (1994) data-based automatic bandwidth } \\
\text { parameter method. All regressions for the PP test include an } \\
\text { intercept and a time trend. The critical values for the PP test - } \\
\text { taken from MacKinnon (1996) - are: }-4.37 \text { ( } 1 \% \text { level), }-3.60 \\
\text { (5\% level), and -3.24 (10\% level). The LM statistics critical } \\
\text { values of the KPSS test - taken from Kwiatkowski et al. } \\
\text { (1992) - are: } 0.2160 \text { (1\% level), } 0.1460 \text { ( } 5 \% \text { level), and } \\
0.1190 \text { (10\% level). }\end{array}$} \\
\hline
\end{tabular}


Finally, we use the estimates to predict and integrate annual growth rates of turnover for the years 1971 to 1978. A graphical representation of turnover in DIY stores from 1970 to 2005 is provided in Figure 5.7.

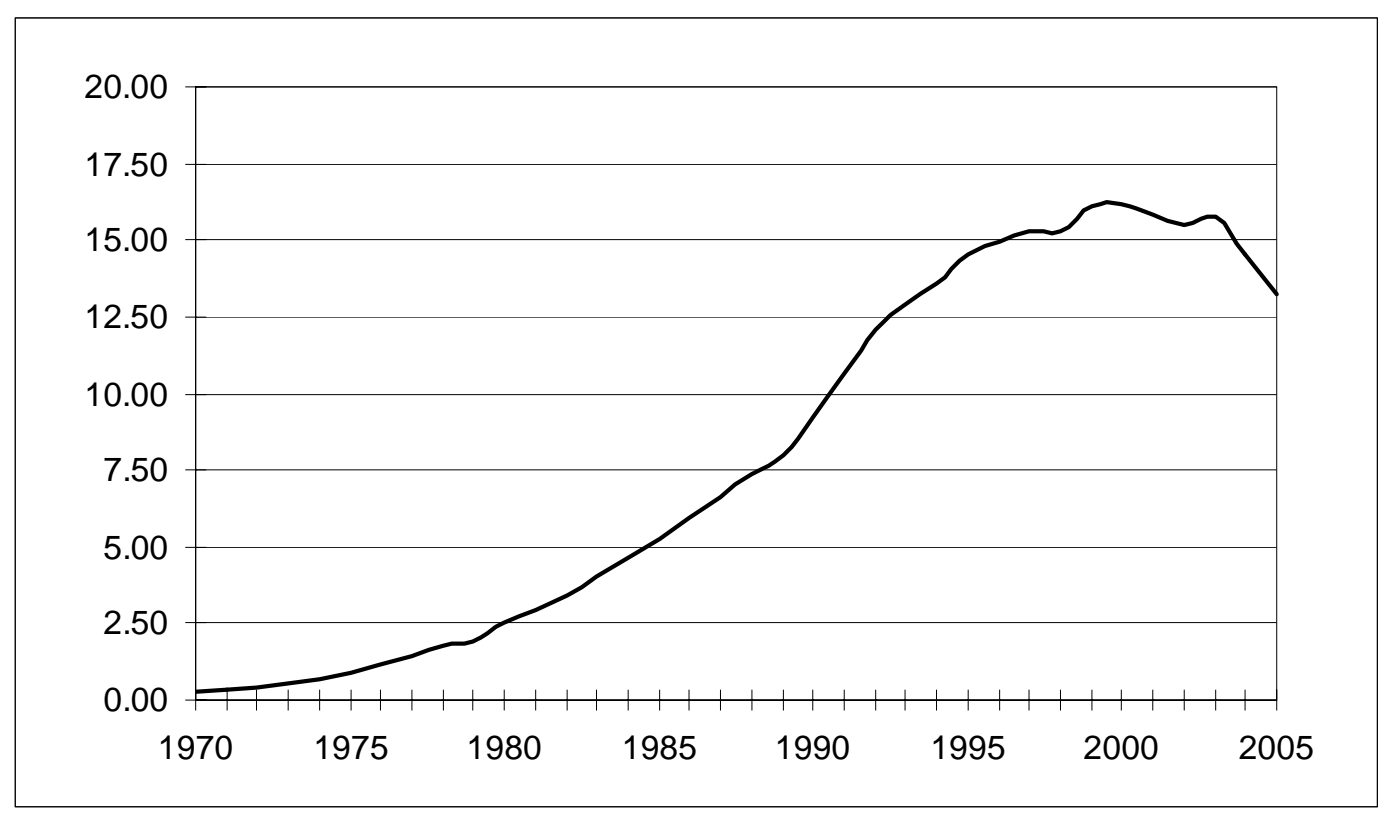

Fig. 5.7 Turnover in DIY stores in Billions of Euros (1970:2005) 


\section{Literature}

Aigner, Dennis; Schneider, Friedrich and Damayanti Ghosh (1988): Me and my shadow: estimating the size of the US hidden economy from time series data, in W. A. Barnett; E. R. Berndt and H. White (eds.): Dynamic econometric modeling, Cambridge (Mass.): Cambridge University Press, pp. 224-243.

Alm, James, Martinez-Vazquez, Jorge and Friedrich Schneider (2004): Sizing the problem of the hard-to-tax, Working Paper, Georgia State University: USA.

Belev, Boyan (2003): The informal economy in the EU Accession Countries: Size, scope, trends and challenges to the process of EU enlargement, Center for Study of Democracy, Sofia.

Brehm, J.W. (1966): A Theory of Psychological Reactance. New York (Academic Press).

Brehm, J.W. (1972): Responses to Loss of Freedom. A Theory of Psychological Reactance. Morristown (General Learning Press).

Dell'Anno, Roberto (2003): Estimating the shadow economy in Italy: A structural equation approach, Discussion Paper, Department of Economics and Statistics, University of Salerno.

Dell'Anno, Roberto and Friedrich Schneider (2004): The shadow economy of Italy and other OECD countries: What do we know?, Discussion Paper, Department of Economics, University of Linz, Linz, Austria.

Deutsche Bundesbank (2002): Der DM-Bargeldumlauf - von der Währungsreform zur Währungsunion, in: Deutsche Bundesbank Monatsbericht März 2002, 54. Jahrgang, Nr. 3, pp 21-35.

Feige, Edgar L. (1989) (ed.): The Underground Economies. Tax Evasion and Information Distortion. Cambridge, New York, Melbourne, Cambridge University Press.

Feige, Edgar L. (1994): The underground economy and the currency enigma, Supplement to Public Finance/ Finances Publiques, 49, pp. 119-136.

Feige, Edgar L. (1996): Overseas holdings of U.S. currency and the underground economy, in: Pozo, Susan (ed.): Exploring the Underground Economy. Kalamazoo, Michigan, pp. 5-62.

Feld, Lars P. and Larsen, Claus (2005): Black activities in Germany in 2001 and 2004: A comparison based on survey data, The Rockwool Foundation Research Unit, Study No. 12, Copenhagen.

Feld, Lars P., Schmidt, Andreas, J. and Schneider, Friedrich (2007): Tax Evasion, Black Activities and Deterrence in Germany: An Institutional and Empirical Perspective, Paper presented at the Public Choice Meeting in Amsterdam, March 29-April 1, 2007.

Fleming, M.H.; Roman, J. and G. Farrel (2000): The shadow economy, Journal of International Affairs, Spring 2000, No. 53/2, pp.64-89. 
Frey, Bruno S. and Hannelore Weck (1983): Estimating the Shadow Economy: A 'Naive' Approach, Oxford Economic Papers, 35, pp. 23-44.

Frey, Bruno S. and Hannelore Weck-Hannemann (1984): The hidden economy as an "unobserved" variable, European Economic Review, 26/1, pp. 33-53.

Frey, Bruno S. and Werner Pommerehne (1984): The hidden economy: State and prospect for measurement, Review of Income and Wealth, 30/1, pp. 123.

Frey, Bruno S. and Weck-Hannemann, Hannelore (1984): The hidden economy as an "unobserved" variable, European Economic Review, 26/1, pp.33-53.

Gerxhani, Klarita (2003): The informal sector in developed and less-developed countries: A literature survey, Public Choice, 114/3-4, pp.295-318.

Giles, David, E.A. (1997a): Causality between the measured and underground economies in New Zealand, Applied Economic Letters, 4, pp.63-67.

Giles, David, E.A. (1997b): Testing the asymmetry in the measured and underground business cycles in New Zealand, Economic Record, 71/1, pp.225-232.

Giles, David, E.A. (1999a): Measuring the hidden economy: Implications for econometric modelling, The Economic Journal, 109/456, pp.370-380.

Giles, David, E.A. (1999b): Modelling the hidden economy in the tax-gap in New Zealand, Empirical Economics, 24/4, pp.621-640.

Giles, David, E.A. (1999c): The rise and fall of the New Zealand underground economy: are the reasons symmetric?, Applied Economic Letters, 6, pp. 185-189.

Giles, David, E.A. and Lindsay M. Tedds (2002): Taxes and the Canadian Underground Economy, Canadian Tax Paper No. 106, Canadian Tax Foundation, Toronto/Ontario.

Giles, David, E.A., Tedds, Lindsay, M. and Werkneh, Gugsa (2002): The Canadian underground and measured economies, Applied Economics, 34/4, pp.2347-2352.

Goldfeld, Stephen M. (1973): The Demand for Money Revisited, Brookings Papers on Economic Activity, 3, pp. 577-638

Greene, William H. (1997), ‘Econometric Analysis’, Prentice Hall International: London et al.

IFD (Institut für Demoskopie Allensbach) (1975): Freizeitarbeit 1974, Studie im Auftrag der Kommission für wirtschaftlichen und sozialen Wandel, Bonn.

Johansen, Søren (1991): Estimation and Hypothesis Testing of Cointegration Vectors in Gaussian Vector Autoregressive Models, Econometrica, 59, 1551-1580.

Johansen, Søren (1995): Likelihood-based Inference in Cointegrated Vector Autoregressive Models, Oxford University Press, Oxford.

Johnson, Simon; Kaufmann, Daniel; and Andrei Shleifer (1997): The unofficial economy in transition, Brookings Papers on Economic Activity, 2, pp. 159221. 
Johnson, Simon; Kaufmann, Daniel and Pablo Zoido-Lobatón (1998a): Regulatory discretion and the unofficial economy. The American Economic Review, 88/ 2, pp. 387-392.

Johnson, Simon; Kaufmann, Daniel and Pablo Zoido-Lobatón (1998b): Corruption, public finances and the unofficial economy. Discussion paper, The World Bank, Washington, D.C.

Karmann, Alexander (1990): Schattenwirtschaft und ihre Ursachen: Eine empirische Analyse zur Schwarzwirtschaft und Selbstversorgung in der Bundesrepublik Deutschland, Zeitschrift für Wirtschafts- und Sozialwissenschaften (ZWS), 110/3, 1990, pp.185-206.

Kirchgaessner, Gebhard (1982): Size and development of the West German shadow economy, 1955-1980, Zeitschrift für die gesamte Staatswissenschaft, 139/2, pp. 197-214.

Kirchgässner, Gebhard (1983): Size and development of West-German shadow economy 1955-1980, Zeitschrift für die gesamte Staatswissenschaft, 139/2, pp.197-214.

Kirchgaessner, Gebhard (1984): Verfahren zur Erfassung des in der Schattenwirtschaft erarbeiteten Sozialprodukts, Allgemeines Statistisches Archiv, 68/4, pp. 378-405.

Kwiatkowski, Denis, Peter C. B. Phillips, Peter Schmidt and Yongcheol Shin (1992): Testing the Null Hypothesis of Stationarity against the Alternative of a Unit Root', Journal of Econometrics, 54, 159-178.

Langfeldt, Enno (1984): The unobserved economy in the Federal Republic of Germany, in: Feige, Edgar L. (ed.): The unobserved economy, Cambridge University Press., pp. 236-260.

Lippert, Owen and Michael Walker (eds.) (1997): The Underground Economy: Global Evidences of its Size and Impact, Vancouver, B.C.: The Frazer Institute.

MacKinnon, James G. (1996): Numerical Distribution Functions for Unit Root and Cointegration Tests, Journal of Applied Econometrics, 11, 601-618.

MacKinnon, James, G., Alfred A. Haug, and Leo Michelis (1999): Numerical Distribution Functions of Likelihood Ratio Tests for Cointegration, Journal of Applied Econometrics, 14, 563-577.

Mummert, Annette and Friedrich Schneider (2001): The German shadow economy: Parted in a united Germany?, Finanzarchiv, 58/3, pp.260-285.

Newey, Whitney and Kenneth West (1994): Automatic Lag Selection in

Covariance Matrix Estimation, Review of Economic Studies, 61, 631-653.

Pelzmann, Linde (1988): Wirtschaftspsychologie. Arbeitslosenforschung, Schattenwirtschaft, Steuerpsychologie. Wien, New York (Springer).

Pedersen, Soren (2003): The Shadow Economy in Germany, Great Britain and Scandinavia: A Measurement Based on Questionnaire Service, Study No. 10, The Rockwoll Foundation Research Unit, Copenhagen. 
Petersen, H.-G.(1982): Size of the public sector, economic growth and the informal economy: Development trends in the Federal Republic of Germany, Review of Income and Wealth, 28/2, pp. 191-215.

Phillips, Peter C.B. and P. Perron (1988): Testing for a Unit Root in Time Series Regression, Biometrika, 75, 335-346.

Pickardt, M. and Sarda Pons, J. (2006): Size and Scope of the Underground Economy in Germany, Applied Economies, 38/4, pp.1707-1713.

Pozo, Susan (ed.) (1996): Exploring the Underground Economy: Studies of Illegal and Unreported Activity, Michigan: W.E. Upjohn, Institute for Employment Research.

Schmidt, Peter and Peter C.B. Phillips (1992): LM tests for a unit root in the presence of deterministic trends, Oxford Bulletin of Economic and Statistics, 54, 257-287.

Schneider, Friedrich (1986): Estimating the size of the Danish shadow economy using the currency demand approach: An attempt, The Scandinavian Journal of Economics, 88/4, pp. 643-668.

Schneider, Friedrich (1994a): Measuring the size and development of the shadow economy. Can the causes be found and the obstacles be overcome? in: Brandstaetter, Hermann, and Güth, Werner (eds.): Essays on Economic Psychology, Berlin, Heidelberg, Springer Publishing Company, pp. 193212.

Schneider, Friedrich (1994b): Can the shadow economy be reduced through major tax reforms? An empirical investigation for Austria, Supplement to Public Finance/ Finances Publiques, 49, pp. 137-152.

Schneider, Friedrich (1997): The shadow economies of Western Europe, Journal of the Institute of Economic Affairs, 17/3, pp. 42-48.

Schneider, Friedrich (1998a): Further empirical results of the size of the shadow economy of 17 OECD-countries over time, Paper presented at the 54. Congress of the IIPF Cordowa, Argentina and discussion paper, Department of Economics, University of Linz, Linz, Austria.

Schneider, Friedrich (1998b): Stellt das Anwachsen der Schwarzarbeit eine wirtschaftspolitische Herausforderung dar? Einige Gedanken aus volkswirtschaftlicher Sicht., Mitteilungen des Instituts für angewandte Wirtschaftsforschung (IAW), I/98, S. 4-13.

Schneider, Friedrich (2000): The increase of the size of the shadow economy of 18 OECD-Countries: Some preliminary explanations, Paper presented at the Annual Public Choice Meeting, March 10-12, 2000, Charleston, S.C.

Schneider, Friedrich (2003): The shadow economy, in: Charles K. Rowley and Friedrich Schneider (eds.), Encyclopedia of Public Choice, Kluwer Academic Publishers, Dordrecht.

Schneider, Friedrich (2005): Shadow economies around the world: what do we really know?, European Journal of Political Economy 21/3, September 2005, pp. 598-642. 
Schneider, Friedrich (2007): Shadow economy and corruption all over the world: what do we know?, Discussion Paper, Department of Economics, University of Linz, Linz, Austria. .

Schneider, Friedrich, Markus F. Hofreither and Reinhard Neck, (1989),The consequences of a changing shadow economy for the official economy: Some empirical results for Austria, in Boes, Dieter and Bernhard Felderer (eds.): The political economy of progressive taxation, Heidelberg: Springer publishing company, pp. 181-211.

Schneider, Friedrich and Dominik Enste (2000): Shadow economies: Size, causes, and consequences, The Journal of Economic Literature, 38/1, pp. 77-114.

Schneider, F., Enste D. (2002). The Shadow Economy: Theoretical Approaches, Empirical Studies, and Political Implications, Cambridge (UK): Cambridge University Press.

Schwert, G. W. (1987): Effects of Model Specification on Tests for Unit Roots in Macroeconomic Data, Journal of Monetary Economics, 20, 73-103.

Seitz, F. (1995): Der DM-Umlauf im Ausland, Volkswirtschaftliche Forschungsgruppe der Deutschen Bundesbank, Bundesbank Diskussionspapier 1/95.

Tanzi, Vito (1999): Uses and abuses of estimates of the underground economy, The Economic Journal, 109/456, pp.338-340.

Thomas, Jim J. (1999): Quantifying the black economy: 'Measurement without Theory’ Yet Again?, The Economic Journal, 109/456, pp. 381-389.

Weck-Hannemann, Hannelore (1983): Schattenwirtschaft: Eine Möglichkeit zur Einschränkung der öffentlichen Verwaltung? Eine ökonomische Analyse, Bern-Frankfurt. 


\section{CESifo Working Paper Series}

(for full list see www.cesifo-group.de)

1956 Panu Poutvaara and Lars-H. R. Siemers, Smoking and Social Interaction, March 2007

1957 Stephan Danninger and Fred Joutz, What Explains Germany's Rebounding Export Market Share?, March 2007

1958 Stefan Krasa and Mattias Polborn, Majority-efficiency and Competition-efficiency in a Binary Policy Model, March 2007

1959 Thiess Buettner and Georg Wamser, Intercompany Loans and Profit Shifting Evidence from Company-Level Data, March 2007

1960 Per Pettersson-Lidbom and Mikael Priks, Behavior under Social Pressure: Empty Italian Stadiums and Referee Bias, April 2007

1961 Balázs Égert and Carol S. Leonard, Dutch Disease Scare in Kazakhstan: Is it real?, April 2007

1962 Paul De Grauwe and Pablo Rovira Kaltwasser, Modeling Optimism and Pessimism in the Foreign Exchange Market, April 2007

1963 Volker Grossmann and Thomas M. Steger, Anti-Competitive Conduct, In-House R\&D, and Growth, April 2007

1964 Steven Brakman and Charles van Marrewijk, It's a Big World After All, April 2007

1965 Mauro Ghinamo, Paolo M. Panteghini and Federico Revelli, FDI Determination and Corporate Tax Competition in a Volatile World, April 2007

1966 Inés Macho-Stadler and David Pérez-Castrillo, Optimal Monitoring to Implement Clean Technologies when Pollution is Random, April 2007

1967 Thomas Eichner and Ruediger Pethig, Efficient $\mathrm{CO}_{2}$ Emissions Control with National Emissions Taxes and International Emissions Trading, April 2007

1968 Michela Redoano, Does Centralization Affect the Number and Size of Lobbies?, April 2007

1969 Christian Gollier, Intergenerational Risk-Sharing and Risk-Taking of a Pension Fund, April 2007

1970 Swapan K. Bhattacharya and Biswa N. Bhattacharyay, Gains and Losses of India-China Trade Cooperation - a Gravity Model Impact Analysis, April 2007

1971 Gerhard Illing, Financial Stability and Monetary Policy - A Framework, April 2007 
1972 Rainald Borck and Matthias Wrede, Commuting Subsidies with two Transport Modes, April 2007

1973 Frederick van der Ploeg, Prudent Budgetary Policy: Political Economy of Precautionary Taxation, April 2007

1974 Ben J. Heijdra and Ward E. Romp, Retirement, Pensions, and Ageing, April 2007

1975 Scott Alan Carson, Health during Industrialization: Evidence from the $19^{\text {th }}$ Century Pennsylvania State Prison System, April 2007

1976 Andreas Haufler and Ian Wooton, Competition for Firms in an Oligopolistic Industry: Do Firms or Countries Have to Pay?, April 2007

1977 Eckhard Janeba, Exports, Unemployment and the Welfare State, April 2007

1978 Gernot Doppelhofer and Melvyn Weeks, Jointness of Growth Determinants, April 2007

1979 Edith Sand and Assaf Razin, The Role of Immigration in Sustaining the Social Security System: A Political Economy Approach, April 2007

1980 Marco Pagano and Giovanni Immordino, Optimal Regulation of Auditing, May 2007

1981 Ludger Woessmann, Fundamental Determinants of School Efficiency and Equity: German States as a Microcosm for OECD Countries, May 2007

1982 Bas Jacobs, Real Options and Human Capital Investment, May 2007

1983 Steinar Holden and Fredrik Wulfsberg, Are Real Wages Rigid Downwards?, May 2007

1984 Cheng Hsiao, M. Hashem Pesaran and Andreas Pick, Diagnostic Tests of Cross Section Independence for Nonlinear Panel Data Models, May 2007

1985 Luis Otávio Façanha and Marcelo Resende, Hierarchical Structure in Brazilian Industrial Firms: An Econometric Study, May 2007

1986 Ondřej Schneider, The EU Budget Dispute - A Blessing in Disguise?, May2007

1987 Sascha O. Becker and Ludger Woessmann, Was Weber Wrong? A Human Capital Theory of Protestant Economic History, May 2007

1988 Erkki Koskela and Rune Stenbacka, Equilibrium Unemployment with Outsourcing and Wage Solidarity under Labour Market Imperfections, May 2007

1989 Guglielmo Maria Caporale, Juncal Cunado and Luis A. Gil-Alana, Deterministic versus Stochastic Seasonal Fractional Integration and Structural Breaks, May 2007

1990 Cláudia Costa Storti and Paul De Grauwe, Globalization and the Price Decline of Illicit Drugs, May 2007 
1991 Thomas Eichner and Ruediger Pethig, Pricing the Ecosystem and Taxing Ecosystem Services: A General Equilibrium Approach, May 2007

1992 Wladimir Raymond, Pierre Mohnen, Franz Palm and Sybrand Schim van der Loeff, The Behavior of the Maximum Likelihood Estimator of Dynamic Panel Data Sample Selection Models, May 2007

1993 Fahad Khalil, Jacques Lawarrée and Sungho Yun, Bribery vs. Extortion: Allowing the Lesser of two Evils, May 2007

1994 Thorvaldur Gylfason, The International Economics of Natural Resources and Growth, May 2007

1995 Catherine Roux and Thomas von Ungern-Sternberg, Leniency Programs in a Multimarket Setting: Amnesty Plus and Penalty Plus, May 2007

1996 J. Atsu Amegashie, Bazoumana Ouattara and Eric Strobl, Moral Hazard and the Composition of Transfers: Theory with an Application to Foreign Aid, May 2007

1997 Wolfgang Buchholz and Wolfgang Peters, Equal Sacrifice and Fair Burden Sharing in a Public Goods Economy, May 2007

1998 Robert S. Chirinko and Debdulal Mallick, The Fisher/Cobb-Douglas Paradox, Factor Shares, and Cointegration, May 2007

1999 Petra M. Geraats, Political Pressures and Monetary Mystique, May 2007

2000 Hartmut Egger and Udo Kreickemeier, Firm Heterogeneity and the Labour Market Effects of Trade Liberalisation, May 2007

2001 Andreas Freytag and Friedrich Schneider, Monetary Commitment, Institutional Constraints and Inflation: Empirical Evidence for OECD Countries since the 1970s, May 2007

2002 Niclas Berggren, Henrik Jordahl and Panu Poutvaara, The Looks of a Winner: Beauty, Gender, and Electoral Success, May 2007

2003 Tomer Blumkin, Yoram Margalioth and Efraim Sadka, Incorporating Affirmative Action into the Welfare State, May 2007

2004 Harrie A. A. Verbon, Migrating Football Players, Transfer Fees and Migration Controls, May 2007

2005 Helmuth Cremer, Jean-Marie Lozachmeur and Pierre Pestieau, Income Taxation of Couples and the Tax Unit Choice, May 2007

2006 Michele Moretto and Paolo M. Panteghini, Preemption, Start-Up Decisions and the Firms' Capital Structure, May 2007 
2007 Andreas Schäfer and Thomas M. Steger, Macroeconomic Consequences of Distributional Conflicts, May 2007

2008 Mikael Priks, Judiciaries in Corrupt Societies, June 2007

2009 Steinar Holden and Fredrik Wulfsberg, Downward Nominal Wage Rigidity in the OECD, June 2007

2010 Emmanuel Dhyne, Catherine Fuss, Hashem Pesaran and Patrick Sevestre, Lumpy Price Adjustments: A Microeconometric Analysis, June 2007

2011 Paul Belleflamme and Eric Toulemonde, Negative Intra-Group Externalities in TwoSided Markets, June 2007

2012 Carlos Alós-Ferrer, Georg Kirchsteiger and Markus Walzl, On the Evolution of Market Institutions: The Platform Design Paradox, June 2007

2013 Axel Dreher and Martin Gassebner, Greasing the Wheels of Entrepreneurship? The Impact of Regulations and Corruption on Firm Entry, June 2007

2014 Dominique Demougin and Claude Fluet, Rules of Proof, Courts, and Incentives, June 2007

2015 Stefan Lachenmaier and Horst Rottmann, Effects of Innovation on Employment: A Dynamic Panel Analysis, June 2007

2016 Torsten Persson and Guido Tabellini, The Growth Effect of Democracy: Is it Heterogenous and how can it be Estimated?, June 2007

2017 Lorenz Blume, Jens Müller, Stefan Voigt and Carsten Wolf, The Economic Effects of Constitutions: Replicating - and Extending - Persson and Tabellini, June 2007

2018 Hartmut Egger and Gabriel Felbermayr, Endogenous Skill Formation and the Source Country Effects of International Labor Market Integration, June 2007

2019 Bruno Frey, Overprotected Politicians, June 2007

2020 Jan Thomas Martini, Rainer Niemann and Dirk Simons, Transfer Pricing or Formula Apportionment? Tax-Induced Distortions of Multinationals' Investment and Production Decisions, June 2007

2021 Andreas Bühn, Alexander Karmann and Friedrich Schneider, Size and Development of the Shadow Economy and of Do-it-yourself Activities in Germany, June 2007 